\title{
Electrophoretically deposited carbon nanotube anchor layer to improve areal capacity of Si-O-C composite anode for lithium secondary batteries
}

\author{
Seongki Ahn ${ }^{\mathrm{a}}$, Moongook Jeong ${ }^{\mathrm{b}}$, Tokihiko Yokoshima ${ }^{\mathrm{c}}$, Hiroki Nara ${ }^{\mathrm{c}}$, Toshiyuki Momma ${ }^{\mathrm{a}, \mathrm{b}, \mathrm{c}}$ and Tetsuya \\ Osaka $^{\mathrm{b}, \mathrm{c} *}$ \\ ${ }^{a}$ Graduate School of Advanced Science and Engineering, Waseda University \\ 3-4-1, Okubo, Shinjuku-ku, Tokyo 169-8555, Japan \\ ${ }^{b}$ Research Organization for Nano and Life Innovation, Waseda University \\ 3-4-1, Okubo, Shinjuku-ku, Tokyo 169-8555, Japan \\ ${ }^{c}$ Research Institute for Science and Engineering, Waseda University \\ 3-4-1, Okubo, Shinjuku-ku, Tokyo 169-8555, Japan \\ *Corresponding author. Tel: +81-3-5286-3202, Fax: +81-3-3205-2074 \\ E-mail: osakatets@waseda.jp
}

(C) 2016. This manuscript version is made available under the Elsevier user license http://www.elsevier.com/open-access/userlicense/1.0/ 


\section{Abstract}

In this study, we report the preparation of carbon nanotubes (CNTs) anchor layer on a $\mathrm{Cu}$ substrate $(\mathrm{CNTs} / \mathrm{Cu})$ by using electrophoretic deposition technique. The CNTs anchor layer increases adhesion strength between $\mathrm{Si}-\mathrm{O}-\mathrm{C}$ composites and $\mathrm{Cu}$ substrate, as a result, it is possible to improve deposited $\mathrm{Si}$ amounts and areal capacity. The electrodeposited Si-O-C composites on $\mathrm{CNTs} / \mathrm{Cu}(\mathrm{Si}-\mathrm{O}-\mathrm{C} / \mathrm{CNTs} / \mathrm{Cu})$ show homogenously coated surface morphology without cracks even large passing charge for electrodeposition of 15 coulomb cm $\mathrm{cm}^{-2}$, resulting in $0.21 \mathrm{mg} \mathrm{cm}^{-2}$ of deposited $\mathrm{Si}$ amounts. On the other hand, Si-O-C composites deposited on as-received $\mathrm{Cu}$ substrate $\left(\mathrm{Si}-\mathrm{O}-\mathrm{C} / \mathrm{Cu}\right.$ ) begin to peel off from substrate at 8 coulomb $\mathrm{cm}^{-2}$ of passing charge, resulting in $0.13 \mathrm{mg} \mathrm{cm}^{-2}$ of deposited Si amounts, and decrease down to 0.10

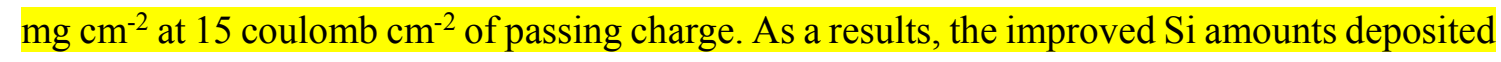
on $\mathrm{CNTs} / \mathrm{Cu}$ substrate achieve higher areal capacity, delivering $0.24 \mathrm{~mA} \mathrm{~h} \mathrm{~cm}^{-2}$, which attains increase in $84.6 \%$ in comparison to $\mathrm{Si}-\mathrm{O}-\mathrm{C} / \mathrm{Cu}$, which has areal capacity of $0.13 \mathrm{~mA} \mathrm{~g} \mathrm{~cm}{ }^{-2}$ at 8 coulomb $\mathrm{cm}^{-2}$ of passing charge. Moreover, the $\mathrm{Si}-\mathrm{O}-\mathrm{C} / \mathrm{CNTs} / \mathrm{Cu}$ shows improved anode performances including discharge capacity and C-rate performance of the Si-O-C composites than $\mathrm{Si}-\mathrm{O}-\mathrm{C} / \mathrm{Cu}$ without $\mathrm{CNTs}$ anchor layer.

Keywords: Electrophoretic deposition, Electrodeposition, Carbon nanotubes, Si-O-C composites, CNTs anchor layer, Li secondary battery. 


\section{Introduction}

Energy conversion system such as solar cell, fuel cell [1,2] and energy storage devices such as capacitor, lithium ion batteries (LIBs) [3,4] have been researched and developed to solve environmental problems such as global warming, severe climate change, and exhaustion of fossil fuel [5-7]. Among them, the LIBs have attracted as next generation energy storage devices because of their outstanding physical and chemical properties like high energy density, no memory effect, and high working voltage. Researches and developments on materials of LIB components, such as cathode and anode active material, electrolyte, separator and so on, have been vigorously carried out to improve their energy and power density, stable cycle ability, low cost, and safety as well for their application on electric vehicles, medical devices, home appliances, and industrial machines in near future [8-10].

Graphite has been widely used as an anode active material due to its low cost, natural abundance, easy handling, eco-friend, and stable intercalation/de-intercalation with Li at low potential ( $\sim 0.1 \mathrm{~V}$ vs. $\left.\mathrm{Li} / \mathrm{Li}^{+}\right)[11]$. For enhanced capacity of anode, carbon nano fiber, carbon nano tubes (CNTs), and graphene have been researched [12-16].

Recently, silicon-based materials have been attracted as a promising anode active material instead of carbon materials because of their light weight, abundance in the nature, and it can alloying/de-alloying with $\mathrm{Li}$ at low working potential ( $\sim 0.5 \mathrm{~V}$ vs. $\left.\mathrm{Li} / \mathrm{Li}^{+}\right)$[17-19]. Moreover, it has higher theoretical capacity than graphite (silicon: $4200 \mathrm{~mA} \mathrm{~h} \mathrm{~g}^{-1}$, graphite: $372 \mathrm{~mA} \mathrm{~h} \mathrm{~g}{ }^{-1}$ ). In spite of these advantages, silicon suffered from volume change up to $400 \%$ during charge/discharge cycling, which lead to severe pulverization of silicon particle, and it lead to loss of electronic contact with active materials and current collector, resulting in fading anode performance. 
Many researches have been studied to overcome above problems by nano-scale silicon size [20, 21], combination with carbon materials [22], surface modification of substrate [23, 24]. For instance, Y. Zhao, et al. synthesized the hierarchical micro/nano porous silicon anode by wet-chemical etching method, which has porous anode material, and it can be endurable the large volume change during charge/discharge process, showing good cycle ability over 50 cycles with good discharge capacity (1500 $\mathrm{mA} \mathrm{h} \mathrm{g}^{-1}$ with the current density of $\left.100 \mathrm{~mA} \mathrm{~h} \mathrm{~g}^{-1}\right)$. In addition, large scale production of silicon-based anode material could be obtained from wetchemical etching method for industrial fields [25]. B. Liu, et al. reported the nanowires-carbon textiles matrix anode without binder materials by spray-coating method. The obtained silicon and carbon composite delivered a high reversible specific capacity $\left(2950 \mathrm{~mA} \mathrm{~h} \mathrm{~g}^{-1}\right.$ at $\left.0.2 \mathrm{C}\right)$, good columbic efficiency of $92 \%$ at $1^{\text {st }}$ cycle, and stable cycle ability for 200 cycles. Moreover, the nanowires-carbon textiles matrix anode can apply to flexible devices due to its flexibility of carbon textiles. The full-cell assembled with nanowires-carbon textiles matrix anode and commercial $\mathrm{LiCoO}_{2}$ cathode shows enhanced reversible discharge capacity $\left(1580 \mathrm{~mA} \mathrm{~h} \mathrm{~g}^{-1}\right.$ at $1 \mathrm{C}$ ) with high coulomb efficiency (ca. 99.7\%). In addition, the designed full-cell demonstrates the stabile voltage profile of $3.24 \mathrm{~V}$ under several situation such as curvature, temperature, and humidity [26]. Furthermore, S. Komaba, et al. researched the sodium polyacrylate (PAANa) as polymer binder for silicon-graphite anode, and its electrochemical properties were compared with Polyvinylidene fluoride (PVdF) binder. The anode prepared with PVdF binder was peeled off from the current collector after charge/discharge. On the other hand, the silicon-graphite anode synthesized with PAANa binder shows stronger adhesion strength even after charge/discharge, which can deliver around $800 \mathrm{~mA} \mathrm{~h} \mathrm{~g}^{-1}$ with good capacity retention [27].

In our previous studies, a novel Si-O-C composites was deposited directly onto copper substrate without binder and conductive additive by electrodeposition from an organic solvent, resulting in high discharge capacity around of $1045 \mathrm{~mA} \mathrm{~h}(\mathrm{~g} \text { of Si})^{-1}$ at $2000^{\text {th }}$ cycle and 842 
$\mathrm{mA} \mathrm{h}(\mathrm{g} \text { of Si})^{-1}$ with the current density of $250 \mu \mathrm{A} \mathrm{cm} \mathrm{cm}^{-2}(1.0 \mathrm{C})$ with outstanding stability over 7200 cycles [28]. Despite the high discharge capacity of Si-O-C composites as anode, it is not easy to obtain the high areal capacity, which is thicker Si-O-C composite film, by Si-O-C electrodeposition because of weak adhesion strength between $\mathrm{Si}-\mathrm{O}-\mathrm{C}$ composites and $\mathrm{Cu}$ substrate, leading the Si-O-C composite to peel off from substrate due to its stress during the electrodeposition. In order to increase the adhesion strength between $\mathrm{Si}-\mathrm{O}-\mathrm{C}$ composites with current collector, new type surface modified substrate, namely nickel micro-nanocones hierarchical structured substrate (NMS), was prepared as current collector via electrodeposition method for Si-O-C electrodeposition. The Si-O-C composites deposited on NMS/Cu substrate achieved improved anode performance, showing high reversible discharge capacity of around $800 \mathrm{~mA} \mathrm{~h}(\mathrm{~g} \text { of Si })^{-1}\left(600 \mu \mathrm{A} \mathrm{h} \mathrm{cm}{ }^{-2}\right)$ with $88 \%$ capacity retention for 100 cycles [29]. Herein, we introduce other way to enhance adhesion strength between $\mathrm{Si}-\mathrm{O}-\mathrm{C}$ composites and $\mathrm{Cu}$ substrate by surface modification of $\mathrm{Cu}$ substrate using CNTs, which have high electric conductivity $\left(5 \times 10^{5} \mathrm{~S} \mathrm{~m}^{-1}\right)$ with lightweight [30-34]. The CNTs deposited $\mathrm{Cu}$ substrate was prepared by electrophoretic deposition with $\mathrm{CoCl}_{2}$ in isopropyl alcohol (IPA) [ref 35]. Electrophoretic deposition method is widely used useful way to synthesize thin layer because it is easy to control the thickness of deposited film and loading amounts by time, voltage, and so on. In addition, surface charge of CNTs can be controlled by various additives such as $\mathrm{Mg}\left(\mathrm{NO}_{3}\right)_{2}, \mathrm{NaOH}, \mathrm{CuCl}_{2}$, and $\mathrm{Al}\left(\mathrm{NO}_{3}\right)_{3}$, and these kinds of materials can effect on their stability of suspension [36-40]. The Si-O-C composites deposited on CNTs anchor layer on a $\mathrm{Cu}$ substrate $(\mathrm{Si}-\mathrm{O}-\mathrm{C} / \mathrm{CNTs} / \mathrm{Cu})$ exhibits increased deposition amounts of $\mathrm{Si}$, resulting in improved areal capacity. Furthermore, it shows high discharge capacity of $1696 \mathrm{~mA} \mathrm{~h}$ (g of Si)${ }^{1}$ at $1^{\text {st }}$ cycle with good cycle ability for $100^{\text {th }}$ cycle and enhanced C-rate performance compared to $\mathrm{Si}-\mathrm{O}-\mathrm{C}$ composites deposited on $\mathrm{Cu}$ substrate $(\mathrm{Si}-\mathrm{O}-\mathrm{C} / \mathrm{Cu})$ without $\mathrm{CNTs}$ anchor layer. This research propose a valuable new method to increase the stability of Si-O-C composites without 
cracks and detachment during electrodeposition by introducing CNTs anchor layer prepared via electrophoretic deposition. 


\section{Experimental}

\subsection{Preparation of CNTs/Cu substrate for Si-O-C composites}

Commercial thin multi-walled CNTs, which has carbon purity around $90 \%$ with diameter around 10nm, were purchased from nanocyl (NC7000). As-received CNTs were oxidized in concentrated $\mathrm{H}_{2} \mathrm{SO}_{4} / \mathrm{HNO}_{3}(3: 1 ; \mathrm{v} / \mathrm{v}$, purity of $96.0 \%$ and $60.0 \%$, respectively) for 4 hours at $45{ }^{\circ} \mathrm{C}$ by sonication to functionalize surface of CNTs, and washed until $\mathrm{pH}$ 7. After washing process, the oxidized CNTs were dried in vacuum oven at $80{ }^{\circ} \mathrm{C}$ for 4 hours. The oxidized CNTs $\left(0.05 \mathrm{mg} \mathrm{ml}^{-1}\right)$ and cobalt dichloride $\left(\mathrm{CoCl}_{2}\right)$ are sonicated in IPA for $30 \mathrm{~min}$ by sonication, separately, followed by both of dispersed samples were sonicated together in same bottle for $30 \mathrm{~min}$ again. The parallel copper substrates with an exposed area of $1 \times 1 \mathrm{~cm}^{-2}$ and a gap of $0.7 \mathrm{~cm}$ were soaked in $\mathrm{CNTs}$ and $\mathrm{CoCl}_{2}$ suspension with glass cell. For electrophoretic deposition, a direct current power supply was used as power resource with a voltage of $-120 \mathrm{~V}$ for 5 minutes. After that, prepared $\mathrm{CNTs} / \mathrm{Cu}$ substrate was washed with distilled water and ethanol to remove aggregated CNTs particles and impurities of their surface. Afterward, the $\mathrm{CNTs} / \mathrm{Cu}$ substrate was dried at room temperature for overnight.

\subsection{Electrodeposition of Si-O-C composites}

For the electrodeposition of $\mathrm{Si}-\mathrm{O}-\mathrm{C}$, as-received $\mathrm{Cu}$ and $\mathrm{CNTs} / \mathrm{Cu}$ substrate, lithium metal, and platinum plate were used as working, reference, and counter electrode, respectively. The propylene carbonate solvent (Kishida), which contain $0.5 \mathrm{~mol} \mathrm{dm}^{-3} \mathrm{SiCl}_{4}$ (Sigma-aldrich) and $0.5 \mathrm{~mol} \mathrm{dm} \mathrm{d}^{-3}$ tetrabuthylammonium perchlorate (Kanto Chemical) was employed as electrolyte for electrodeposition, and the Si-O-C electrodeposition was carried out in argon-filled globe box with dew point lower than $-90^{\circ} \mathrm{C}$. A constant cathodic current of $-1.0 \mathrm{~mA} \mathrm{~cm}{ }^{-2}$ was applied to pass a charge of $2,4,8$, and 15 coulomb $\mathrm{cm}^{-2}$ for the electrodeposition. 


\subsection{Measurement of Si-O-C composites}

The morphological properties of $\mathrm{Si}-\mathrm{O}-\mathrm{C} / \mathrm{CNTs} / \mathrm{Cu}$ were characterized by field emission scanning electron microscopy (FE-SEM, Hitachi, S-4800) with energy dispersive X-ray spectroscopy (SEM, Hitachi TM-3000). The surface properties of Si-O-C/CNTs/Cu, which was moved into transfer vessel to prevent oxidization of silicon, were measured by X-ray photoelectron spectroscopy (XPS, JEOL, JPS-9010TR). The deposited Si amounts were measured by inductively coupled plasma (ICP, Thermo Scientific, iCAP6500 Duo) analysis.

\subsection{Electrochemical analysis of Si-O-C/Cu and $\mathrm{Si}-\mathrm{O}-\mathrm{C} / \mathrm{CNTs} / \mathrm{Cu}$}

The electrochemical cell of Si-O-C composites deposited on ac-received $\mathrm{Cu}$ substrate and CNTs anchor layer on $\mathrm{Cu}$ substrate was equipped containing $1.0 \mathrm{~mol} \mathrm{dm}^{-3}$ lithium perchlorate $\left(\mathrm{LiClO}_{4}\right)$ in propylene carbonate-ethylene carbonate $(\mathrm{PC}: \mathrm{EC}=1: 1, \mathrm{v} / \mathrm{v})$ as electrolyte (Kishida) in a glove box with dew point below $-110{ }^{\circ} \mathrm{C}$, using coin type cell (2032 type). Cyclic voltammograms $(\mathrm{CV})$ of as-receive $\mathrm{Cu}, \mathrm{CNTs} / \mathrm{Cu}$ substrate and $\mathrm{Si}-\mathrm{O}-\mathrm{C} / \mathrm{CNTs} / \mathrm{Cu}$ was measured in the potential range of $0.01-1.20 \mathrm{~V} \mathrm{vs} . \mathrm{Li}^{\prime} \mathrm{Li}^{+}$at a scan rate of $0.1 \mathrm{mV} \mathrm{s}^{-1}$ (Hokuto Denko, HZ-5000). Electrochemical properties of $\mathrm{Si}-\mathrm{O}-\mathrm{C} / \mathrm{Cu}$ and $\mathrm{Si}-\mathrm{O}-\mathrm{C} / \mathrm{CNTs} / \mathrm{Cu}$ were investigated by a constant current charge/discharge measurement with $0.1 \mathrm{C}$-rate in the potential range between $0.01-1.20 \mathrm{~V}$ vs. $\mathrm{Li} / \mathrm{Li}^{+}$, and the $\mathrm{C}$-rate was calculated depending on deposited Si amounts by ICP measurement. 


\section{Results and discussion}

(a)

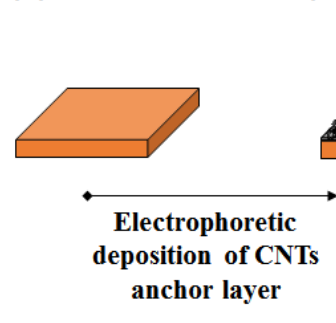

(b)

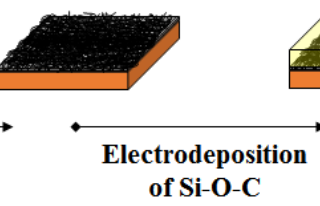

(c)

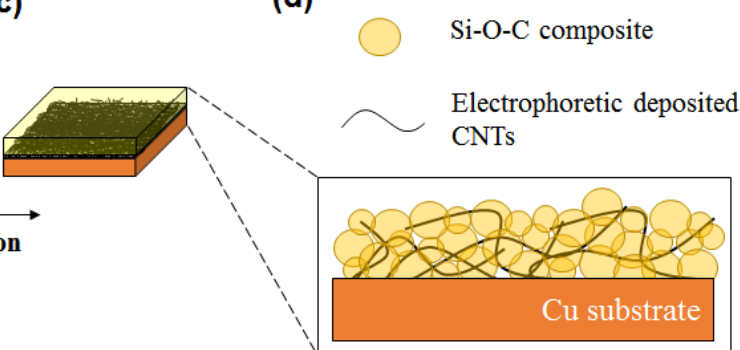

Figure 1. Schematic figures explaining Si-O-C composites deposition process on $\mathrm{CNTs} / \mathrm{Cu}$ Substrate; (a) asreceived $\mathrm{Cu}$ substrate, (b) electrophoretically deposited CNTs anchor layer on $\mathrm{Cu}$ substrate, (c) electrodeposited $\mathrm{Si}-\mathrm{O}-\mathrm{C}$ on $\mathrm{CNTs} / \mathrm{Cu}$ substrate, and (d) $\mathrm{Si}-\mathrm{O}-\mathrm{C} / \mathrm{CNTs} / \mathrm{Cu}$ anode with cross-section view.

Figure 1 illustrates a preparation process of $\mathrm{CNTs} / \mathrm{Cu}$ substrate supporting $\mathrm{Si}-\mathrm{O}-\mathrm{C}$ composites. The CNTs anchor layer was deposited on as-received $\mathrm{Cu}$ substrate by electrophoretic deposition as presented in Fig. 1 (b). Subsequently, Si-O-C electrodeposition was carried out on the obtained $\mathrm{CNTs} / \mathrm{Cu}$ substrate in Fig. 1 (c). The Si-O-C composites are deposited on CNTs anchor layer which might contribute to improve deposited Si amounts. It is supposed that the Si-O-C composites were electrodeposited by filling inside of CNT layer, lead to increase adhesion between Si-O-C with $\mathrm{Cu}$ substrate (see Fig. 1 (d)). 

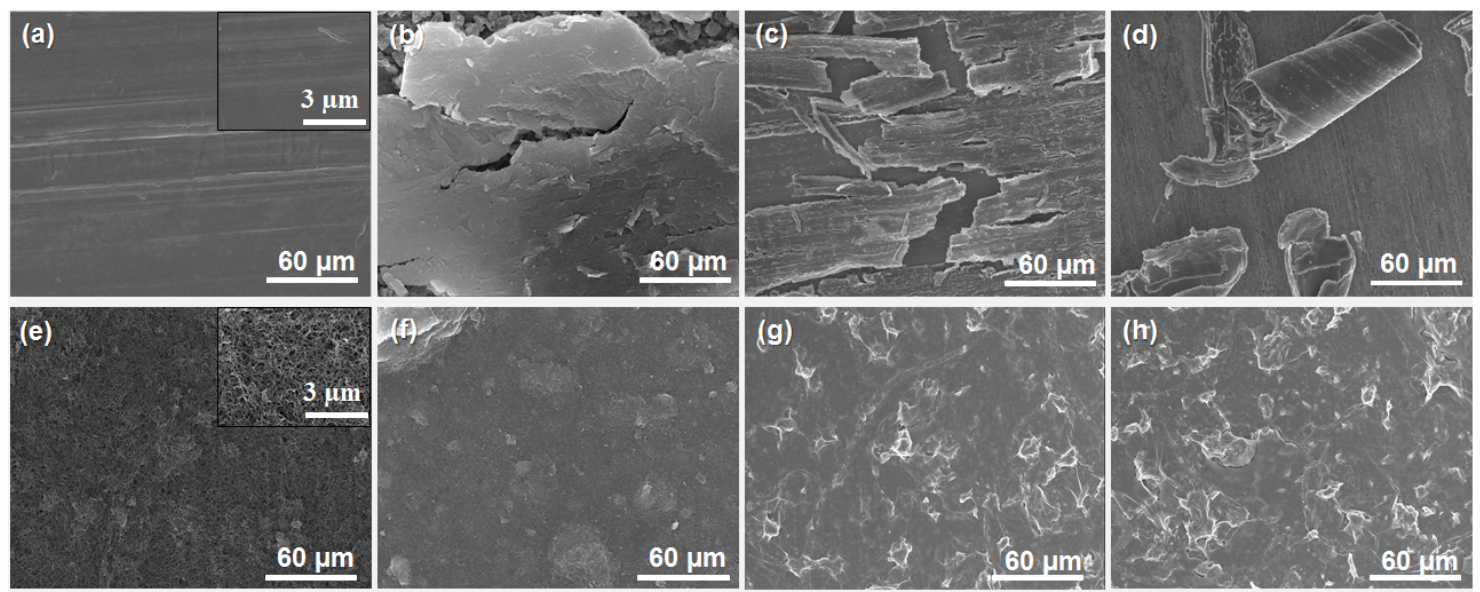

Figure 2. Plane view FE-SEM images of (a) as-received $\mathrm{Cu}$ substrate, and Si-O-C composites deposited on asreceived $\mathrm{Cu}$ substrate at (b) 2, (c) 8 , and (d) 15 coulomb $\mathrm{cm}^{-2}$ passing charge. The plane view of (e) $\mathrm{CNTs} / \mathrm{Cu}$ substrate, Si-O-C composites deposited on CNTs/Cu substrate at (f) 2, (g) 8, and (h) 15 coulomb $\mathrm{cm}^{-2}$ of passing charge.

Figure 2 shows plane view FE-SEM images of as-received $\mathrm{Cu}$ substrate, $\mathrm{CNTs} / \mathrm{Cu}$ substrate, and after Si-O-C deposition on them depending on quantity of electricity for electrodeposition from 2 to 15 coulomb $\mathrm{cm}^{-2}$ of passing charge. Figure 2 (a) shows a typical surface morphologies of as-received $\mathrm{Cu}$ substrate, which is smooth without any grainy and with marks caused by rolling $\mathrm{Cu}$ plate through rolls. By contrast, it is shown that the CNTs are densely covering $\mathrm{Cu}$ substrate via electrophoretic deposition and the CNTs/Cu substrate formed three-dimensional (3D) structure in Fig.2 (e). The unique surface morphologies of CNTs/Cu substrate may have many features such as higher surface area than as-received $\mathrm{Cu}$ substrate and higher adhesion strength between $\mathrm{Si}-\mathrm{O}-\mathrm{C}$ composites with $\mathrm{Cu}$ substrate, resulting in enhanced deposited $\mathrm{Si}$ amount without peeling off and electrochemical properties. After Si-O-C electrodeposition, surface morphologies of $\mathrm{Si}-\mathrm{O}-\mathrm{C} / \mathrm{Cu}$ and $\mathrm{Si}-\mathrm{O}-\mathrm{C} / \mathrm{CNTs} / \mathrm{Cu}$ are remarkably different as shown in Fig. 2 (b)-(d) and Fig. 2 (f)-(h), respectively. In Fig. 2 (b), Si-O-C composites deposited on as-received $\mathrm{Cu}$ substrate at 2 coulomb $\mathrm{cm}^{-2}$ of passing charge shows cracked surface. In 
addition, after electrodeposition at 8 and 15 coulomb cm${ }^{-2}$ of passing charge, the plane view of both samples depicts the peeled off $\mathrm{Si}-\mathrm{O}-\mathrm{C}$ composites from $\mathrm{Cu}$ substrate because of its stress and weak adhesion strength between $\mathrm{Si}-\mathrm{O}-\mathrm{C}$ composites and $\mathrm{Cu}$ substrate. On the other hand, $\mathrm{Si}-\mathrm{O}-\mathrm{C} / \mathrm{CNTs} / \mathrm{Cu}$ have homogeneous surface without any cracks at 2, 8, and even 15 coulomb $\mathrm{cm}^{-2}$ of passing charge owing to increased adhesion strength. It reveals that the CNTs layer is related to adhesion strength, resulting in non-cracked surface of $\mathrm{Si}-\mathrm{O}-\mathrm{C} / \mathrm{CNTs} / \mathrm{Cu}$ as shown in Fig. 2 (f)-(h). From these results, we suggest that CNTs anchor layer can hold and sustain each Si-O-C composite particles during electrodeposition, resulting in enhanced adhesion strength and improved structural stability. 

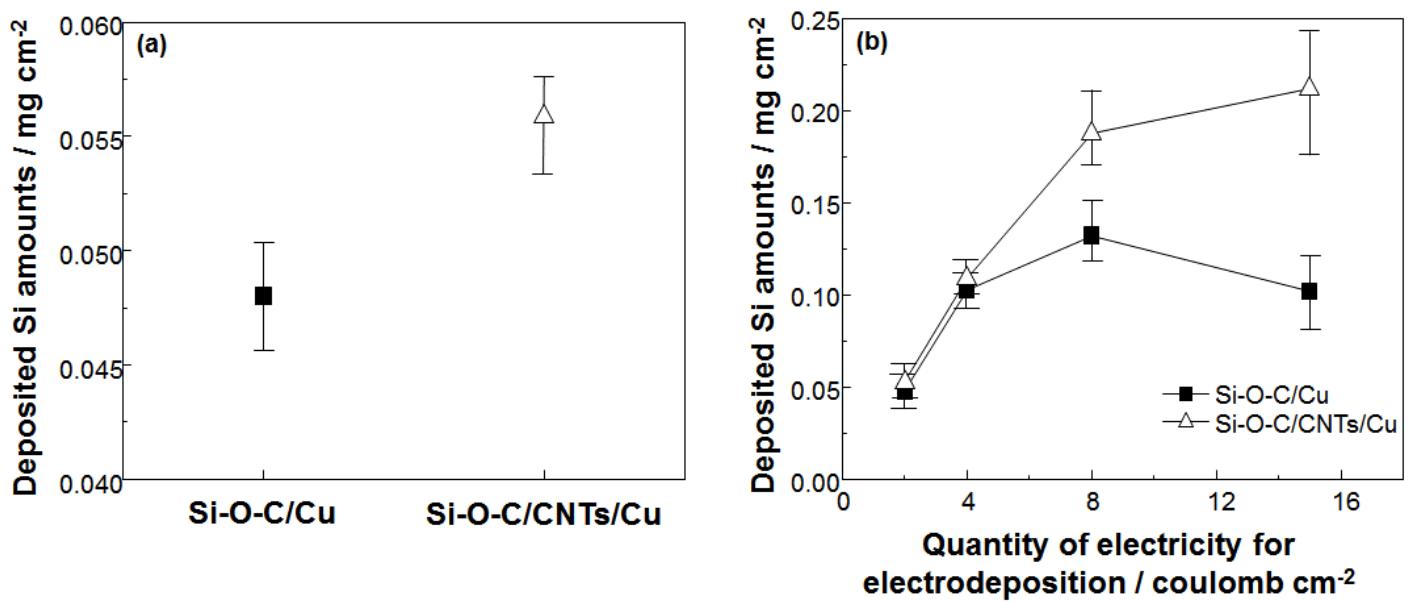

Figure 3. (a) Comparison of deposited $\mathrm{Si}$ amounts of Si-O-C composites deposited onto as-received $\mathrm{Cu}$ substrate and $\mathrm{CNTs} / \mathrm{Cu}$ substrate at 2 coulomb $\mathrm{cm}^{-2}$ of passing charge, and (b) depending on various quantity of electricity for electrodeposition from 2 to 15 coulomb $\mathrm{cm}^{-2}$ of passing charge.

The deposited $\mathrm{Si}$ amounts of $\mathrm{Si}-\mathrm{O}-\mathrm{C} / \mathrm{Cu}$ and $\mathrm{Si}-\mathrm{O}-\mathrm{C} / \mathrm{CNTs} / \mathrm{Cu}$ prepared by 2 coulomb $\mathrm{cm}^{-2}$ of passing charge were measured by ICP analysis. The average deposited Si amounts of Si-O$\mathrm{C} / \mathrm{Cu}$ and $\mathrm{Si}-\mathrm{O}-\mathrm{C} / \mathrm{CNTs} / \mathrm{Cu}$ are 0.048 and $0.056 \mathrm{mg} \mathrm{cm}^{-2}$, respectively (see in Fig. 3 (a)). The $\mathrm{Si}-\mathrm{O}-\mathrm{C} / \mathrm{CNTs} / \mathrm{Cu}$ has higher deposited $\mathrm{Si}$ amount than $\mathrm{Si}-\mathrm{O}-\mathrm{C} / \mathrm{Cu}$ up to $16.7 \%$ because the $\mathrm{CNTs} / \mathrm{Cu}$ substrate is able to maintain the high electric conductivity during electrodeposition, resulting in higher electrodeposition efficiency than as-receive $\mathrm{Cu}$ substrate. In addition, it can be expected that increasing of deposited Si amounts shows increased areal capacity. Table S1 shows the deposited $\mathrm{Si}$ amounts of $\mathrm{Si}-\mathrm{O}-\mathrm{C} / \mathrm{Cu}$ and $\mathrm{Si}-\mathrm{O}-\mathrm{C} / \mathrm{CNTs} / \mathrm{Cu}$ synthesized at 2 coulomb $\mathrm{cm}^{-2}$ of passing charge. Electrodeposition of the Si-O-C composites on either as-received $\mathrm{Cu}$ or $\mathrm{CNTs} / \mathrm{Cu}$ substrate was prepared and their ICP measurements were carried out to test the reproducibility of Si-O-C electrodeposition. From these results, we could confirm that the method of Si-O-C electrodeposition from organic solvent has good reproducibility. Figure 3 (b) shows the deposited $\mathrm{Si}$ amounts of $\mathrm{Si}-\mathrm{O}-\mathrm{C} / \mathrm{Cu}$ and $\mathrm{Si}-\mathrm{O}-\mathrm{C} / \mathrm{CNTs} / \mathrm{Cu}$ depending on quantity of electricity for electrodeposition at 2, 4, 8, and 15 coulomb cm-2. At 2 and 4 coulomb $\mathrm{cm}^{-2}$ of 
passing charge, each samples show almost same deposited Si amounts of 0.05 and $0.10 \mathrm{mg} \mathrm{cm}^{-}$

${ }^{2}$, respectively. However, $\mathrm{Si}-\mathrm{O}-\mathrm{C} / \mathrm{Cu}$ has highest deposited $\mathrm{Si}$ amounts of $0.13 \mathrm{mg} \mathrm{cm} \mathrm{cm}^{-2}$ at 8 coulomb cm- ${ }^{2}$ of passing charge and started to decrease until $0.10 \mathrm{mg} \mathrm{cm}^{-2}$ at 15 coulomb $\mathrm{cm}^{-}$ ${ }^{2}$ of passing charge because deposited Si-O-C composites begin to peel off from as-received $\mathrm{Cu}$ substrate. By contrast, deposited $\mathrm{Si}$ amounts of $\mathrm{Si}-\mathrm{O}-\mathrm{C} / \mathrm{CNTs} / \mathrm{Cu}$ continued to increase and the deposited Si amounts are 0.18 and $0.21 \mathrm{mg} \mathrm{cm}^{-2}$ at 8 and 15 coulomb cm $\mathrm{cm}^{-2}$ of passing charge, respectively. It reveals that the adhesion strength between $\mathrm{Si}-\mathrm{O}-\mathrm{C}$ composites and $\mathrm{Cu}$ substrate was enhanced by introducing of CNTs anchor layer. Moreover, we can suppose that CNTs layer increased structural stability of Si-O-C composites as well, resulting in non-cracked surface of Si-O-C composites, which is corresponding to Fig. 2. 

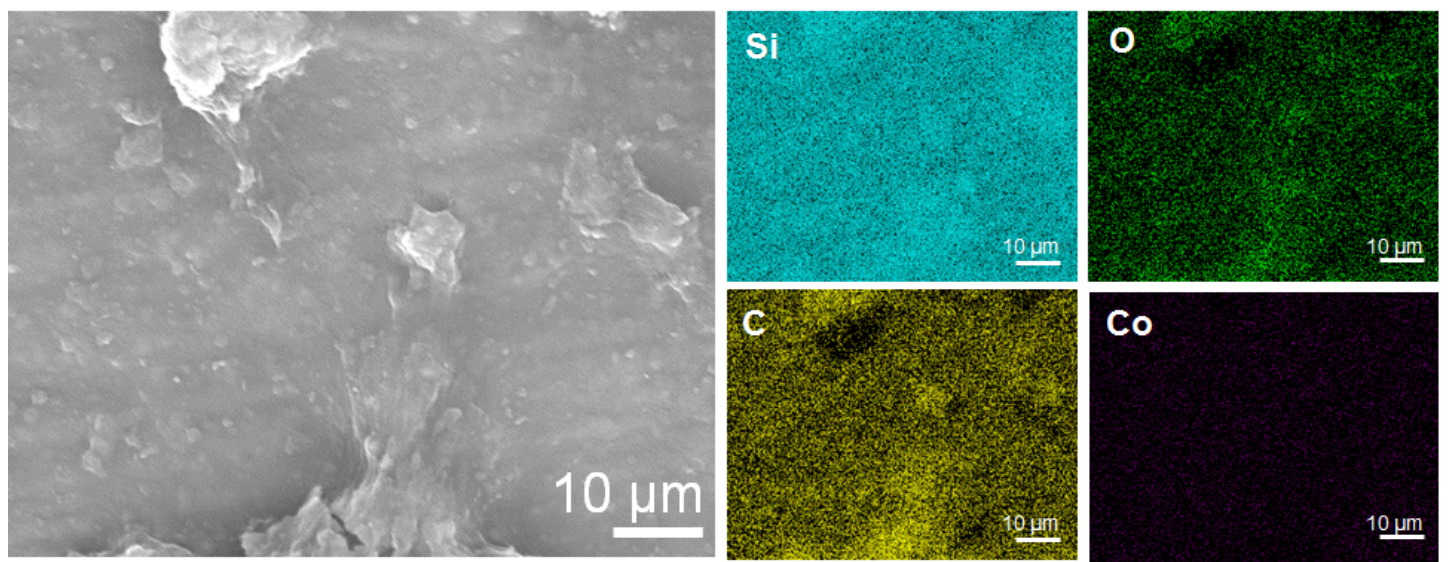

Figure 4. Plane view SEM image of $\mathrm{Si}-\mathrm{O}-\mathrm{C} / \mathrm{CNTs} / \mathrm{Cu}$ prepared by electrodeposition at 2 coulomb $\mathrm{cm}^{-2}$ of passing charge with elemental mapping of silicon, oxygen, carbon and cobalt.

Figure 4 shows plane view SEM image of $\mathrm{Si}-\mathrm{O}-\mathrm{C} / \mathrm{CNTs} / \mathrm{Cu}$ prepared by electrodeposition at 2 coulomb $\mathrm{cm}^{-2}$ of passing charge with elemental mapping of Si. O, C, and Co. The results of elemental mapping depict that $\mathrm{Si}, \mathrm{O}$, and $\mathrm{C}$ were homogenously deposited on $\mathrm{CNTS} / \mathrm{Cu}$ substrate. However, cobalt was not detected clearly from surface of Si-O-C/CNTs/Cu because of their very small quantity, which has around of $0.525 \mu \mathrm{g} \mathrm{cm}^{-2}$. The detail information of deposited Co amounts and their effectiveness related to CNTs electrophoretic deposition is shown in Fig. S1, S2 and Table S2. From these results, we suppose that the small amounts of Co cannot interfere in electrochemical performance of Si-O-C composites as anode for LIB. In addition, it is important to find the appropriate amounts of Co because exceed amounts of cobalt might be a resistance material, which can effect on electrochemical properties of Si-O-C composites. Therefore, we confirmed that the appropriate amounts of Co were used to impart positive charge on surface of CNTs during electrophoretic deposition. 

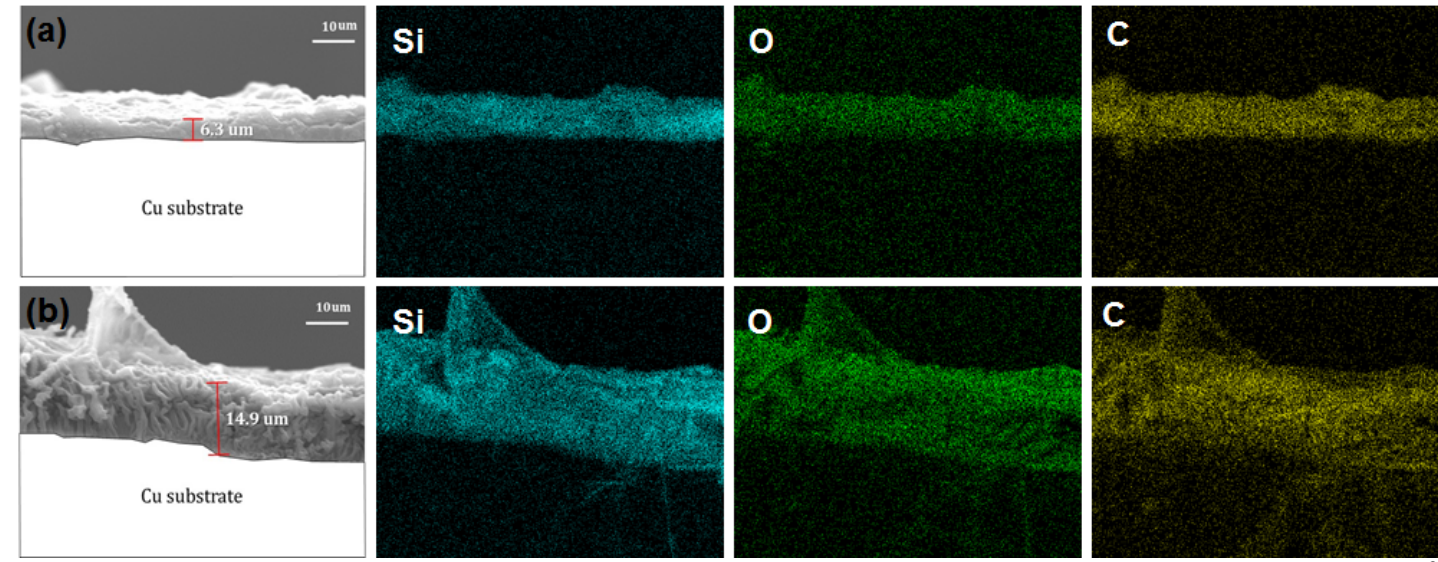

Figure 5. SEM images of cross-section of Si-O-C/CNTs/Cu prepared by electrodeposition at 2 coulomb $\mathrm{cm}^{-2}$ of passing charge (a) before and (b) after charge/discharge with elemental mapping of silicon, oxygen, and carbon.

The cross-section SEM images of $\mathrm{Si}-\mathrm{O}-\mathrm{C} / \mathrm{CNTs} / \mathrm{Cu}$ prepared by electrodeposition at 2 coulomb cm $\mathrm{cm}^{-2}$ of passing charge before and after charge/discharge process for 100 cycles with EDX elemental mapping of $\mathrm{Si}, \mathrm{O}$, and $\mathrm{C}$ are shown in Fig. 5 (a) and (b), respectively. The homogenous dispersion of each elemental, i.e. $\mathrm{Si}, \mathrm{O}$, and $\mathrm{C}$ are also observed before and after charge/discharge. However, EDX elemental mapping of Co was not detected because of their very small quantity (not shown here), which is corresponding to that of Fig. 4. Figure 5 (a) shows the cross-section image of $\mathrm{Si}-\mathrm{O}-\mathrm{C} / \mathrm{CNTs} / \mathrm{Cu}$ before charge/discharge process, which has thickness of $6.3 \mu \mathrm{m}$. After charge/discharge process for 100 cycles, the thickness of Si-O$\mathrm{C} / \mathrm{CNTs}$ layer (discharge state) was increased up to $14.9 \mu \mathrm{m}$ because of volume expansion of Si during lithiation at $1^{\text {st }}$ cycle, and this behavior is corresponding in our previous report (shown in Fig. 5 (b)) [28]. In addition, we confirmed that the elementals of $\mathrm{Si}$, O, and $\mathrm{C}$ were homogeneously dispersed before and after charge/discharge process for 100 cycles, and it means that $\mathrm{Si}-\mathrm{O}-\mathrm{C}$ composites deposited on $\mathrm{CNTs} / \mathrm{Cu}$ substrate has good stability even after volume change.

Additional result related existence of Co was measured by XPS analysis before and after charge/discharge process for 100 cycles and presented in Fig. S3. The peak change of Co2p3 
was not detected in the narrow peak before and after charge/discharge (in Fig. S3 (a)). Therefore, we suppose that the very small quantities of cobalt, which deposited on to CNTs surface, cannot influence electrochemical reaction with Si-O-C composites, and it is corresponding to results of elemental mapping in Fig. 4. As seen the spectrum of $\mathrm{C}_{1}$ in Fig. S3 (b), only one peak was observed before charge/discharge cycling at the around $284.4 \mathrm{eV}$. After charge/discharge for 100 cycles, the peak located at the around $284.4 \mathrm{eV}$ was decreased, and a new peak was detected at the around $289.8 \mathrm{eV}$, attributed to carbonate peak including $\mathrm{Li}_{2} \mathrm{CO}_{3}$ and $\mathrm{R}-\mathrm{CH}_{2} \mathrm{OCO}_{2} \mathrm{Li}$. Moreover, the peak located at the around $284.4 \mathrm{eV}$ has lower intensity than our previously study [28]. We suggest that the reason for lower intensity of $\mathrm{C}_{1 \mathrm{~s}}$ peak after charge/discharge is concentration change of each elemental of $\mathrm{Si}, \mathrm{O}$, and $\mathrm{C}$ because of change of electric conductivity by existence of CNTs layer. Figure S4 shows the glow discharge optical emission spectroscopy (GDOES) results of $\mathrm{Si}-\mathrm{O}-\mathrm{C} / \mathrm{Cu}$ and $\mathrm{Si}-\mathrm{O}-\mathrm{C} / \mathrm{CNTs} / \mathrm{Cu}$ prepared by electrodeposition at 2 coulomb $\mathrm{cm}^{-2}$ of passing charge. The concentration of $\mathrm{Si}, \mathrm{O}$, and $\mathrm{C}$ of $\mathrm{Si}-\mathrm{O}-\mathrm{C} / \mathrm{Cu}$ and $\mathrm{Si}-\mathrm{O}-\mathrm{C} / \mathrm{CNTs} / \mathrm{Cu}$ was different because of differential electric conductivity of as-received $\mathrm{Cu}$ substrate and $\mathrm{CNTs} / \mathrm{Cu}$ substrate during electrodeposition. For more specific reasons, related research should to be focused in our future study. 

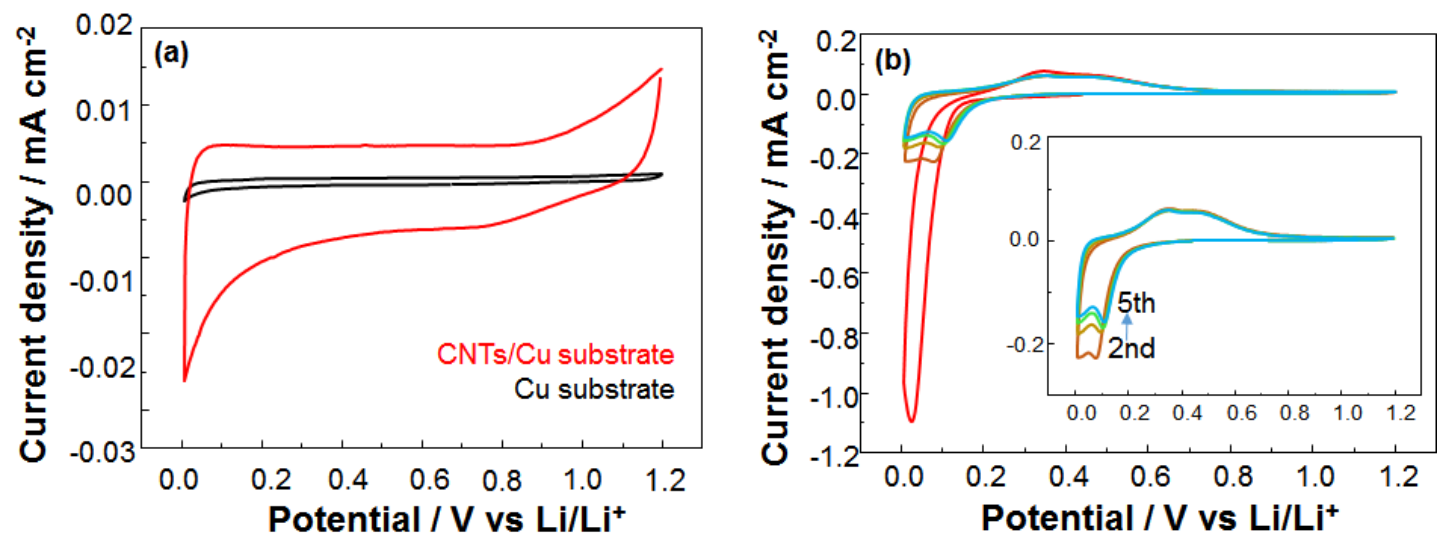

Figure 6. $\mathrm{CV}$ results of (a) as-receive $\mathrm{Cu}$ and $\mathrm{CNTs} / \mathrm{Cu}$ substrate and (b) $\mathrm{Si}-\mathrm{O}-\mathrm{C} / \mathrm{CNTs} / \mathrm{Cu}$ for 5 cycles synthesized by electrodeposition with 2 coulomb cm $\mathrm{cm}^{-2}$ of passing charge. The potential range is between 1.2 and $0.01 \mathrm{~V}$ vs. $\mathrm{Li} / \mathrm{Li}^{+}$at a scan rate of $0.1 \mathrm{mV} \mathrm{s}^{-1}$. The inset in (b) indicates the enlarged $\mathrm{CV}$ results of $\mathrm{Si}-\mathrm{O}-\mathrm{C} / \mathrm{CNTs} / \mathrm{Cu}$ from $2^{\text {nd }}$ to $5^{\text {th }}$ cycle.

$\mathrm{CV}$ measurements were carried out to compare the surface area of as-received $\mathrm{Cu}$ and $\mathrm{CNTs} / \mathrm{Cu}$ substrate in the potential range between 0.01 and $1.2 \mathrm{~V}$ at a scan rate of $0.1 \mathrm{mV} \mathrm{s}^{-1}$ in Fig. 6 (a). These both substrates show the electric double layer capacitor behavior without any peaks related to lithiation. As can be seen in Fig. 6 (a), it is clear that the CNTs/Cu substrate shows higher capacitance of $7.54 \mathrm{mF} \mathrm{cm}^{-2}$ than as-received $\mathrm{Cu}$ substrate, which has capacitance of $0.57 \mathrm{mF} \mathrm{cm}^{-2}$ owing to their higher surface area by 3D structured CNTs anchor layer. These results mean that the surface area of $\mathrm{Cu}$ substrate was increased by CNTs anchor layer and implies that the $\mathrm{CNTs} / \mathrm{Cu}$ substrate can react more with electrolyte containing $\mathrm{SiCl}_{4}$ during electrodeposition. The $\mathrm{CV}$ results of Si-O-C composites deposited onto $\mathrm{CNTs} / \mathrm{Cu}$ substrate prepared at 2 coulomb $\mathrm{cm}^{-2}$ of passing charge are shown in Fig. 6 (b) for 5 cycles. At $1^{\text {st }}$ cycle, a huge cathodic peak was started at ca. $0.1 \mathrm{~V}$ vs. $\mathrm{Li} / \mathrm{Li}^{+}$due to conversation reaction of $\mathrm{SiO}_{\mathrm{x}}$ and formation of SEI on surface on Si-O-C composites, which lead to huge irreversible capacity at $1^{\text {st }}$ cycle [29]. After $2^{\text {nd }}$ cycle, the lithiation with $\mathrm{Si}$ was started at the around $0.2 \mathrm{~V} \mathrm{vs}$. $\mathrm{Li} / \mathrm{Li}^{+}$, resulting in formation of amorphous- $\mathrm{Li}_{\mathrm{x}} \mathrm{Si}_{\mathrm{y}}$ phase. In addition, the reaction peaks of delithiation of $\mathrm{Li}_{\mathrm{x}} \mathrm{Si}_{\mathrm{y}}$ forward to amorphous-Si was detected at 0.37 and $0.50 \mathrm{~V}$ vs. $\mathrm{Li} / \mathrm{Li}^{+}$. From $\mathrm{CV}$ results 
of $\mathrm{Si}-\mathrm{O}-\mathrm{C}$ composites for $5^{\text {th }}$ cycle, it reveal that irreversible capacity at $1^{\text {st }}$ cycle was disappeared after $2^{\text {nd }}$ cycle because almost reactions related to formation of SEI on Si-O-C composites surface and conversion or lithiation of $\mathrm{SiO}_{\mathrm{x}}$ are finished at $1^{\text {st }}$ cycle. 

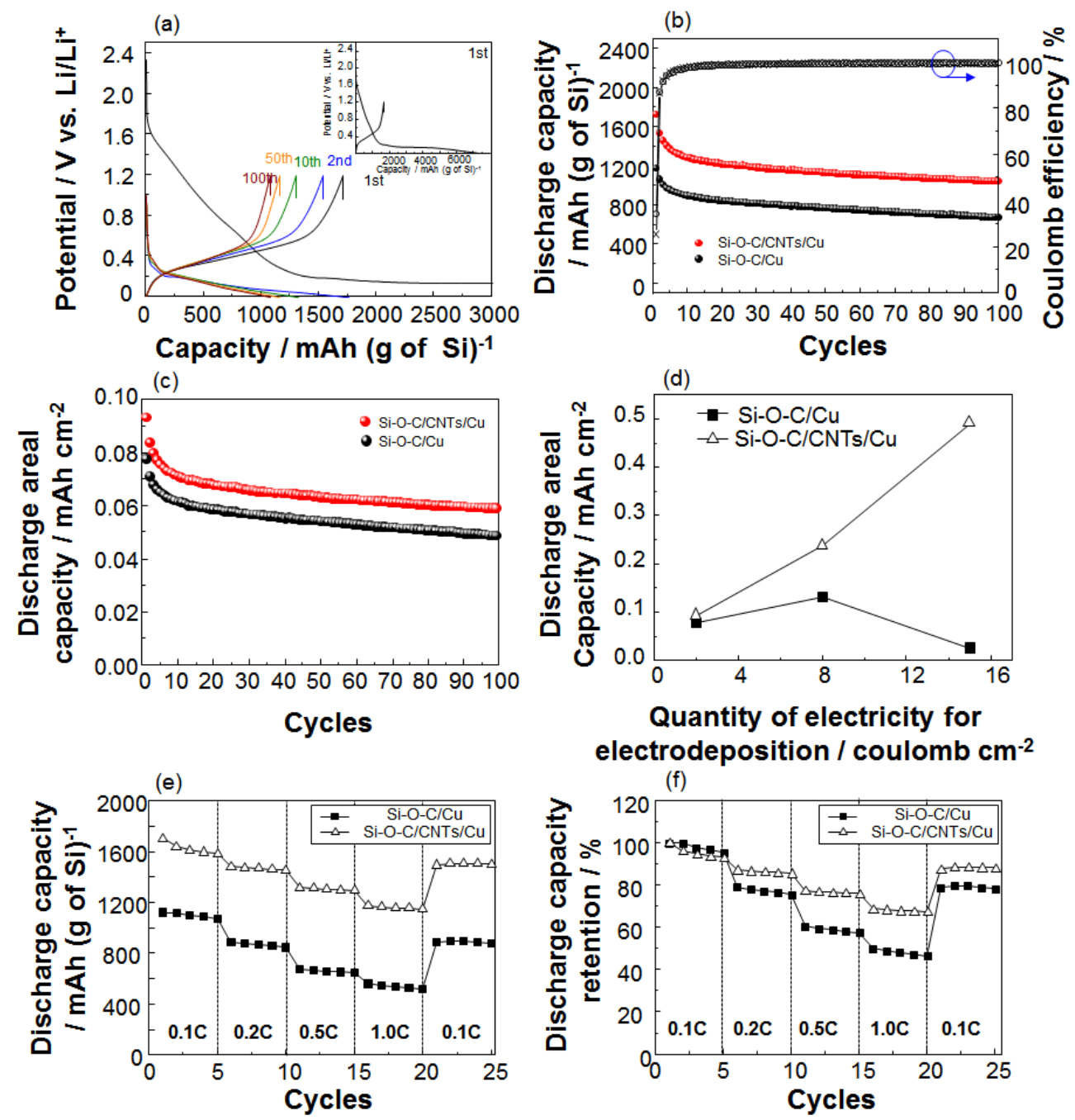

Figure 7. (a) Charge/discharge profiles of $\mathrm{Si}-\mathrm{O}-\mathrm{C} / \mathrm{CNTs} / \mathrm{Cu}$ from $1^{\text {st }}$ to $100^{\text {th }}$ cycle, the potential range is $0.01-1.2$ $\mathrm{V}$ vs. $\mathrm{Li} / \mathrm{Li}^{+}$at $0.1 \mathrm{C}$-rate, (b) comparison of cycle abilities with $\mathrm{Si}-\mathrm{O}-\mathrm{C} / \mathrm{Cu}$ and $\mathrm{Si}-\mathrm{O}-\mathrm{C} / \mathrm{CNTs} / \mathrm{Cu}$ for 100 cycles, (c) discharge areal capacity of both samples, (d) areal capacity depending on quantity of electricity from 2 to 15 coulomb $\mathrm{cm}^{-2}$ of passing charge at $1^{\text {st }}$ cycle, (e) C-rate performance, and (f) discharge capacity retention rate at various $\mathrm{C}$-rate from 0.1 to $1 \mathrm{C}$ and $0.1 \mathrm{C}$ again for 25 cycles. (a) - (d) were tested at $0.1 \mathrm{C}$-rate. The discharge capacity values of $\mathrm{Si}-\mathrm{O}-\mathrm{C} / \mathrm{Cu}$ and $\mathrm{Si}-\mathrm{O}-\mathrm{C} / \mathrm{CNTs} / \mathrm{Cu}$ were normalized with the calculated $\mathrm{Si}$ amounts from ICP results. The all Si-O-C composites were synthesized by electrodeposition with 2 coulomb $\mathrm{cm}^{-2}$ of passing charge except to (d).

The charge/discharge potential profiles of $\mathrm{Si}-\mathrm{O}-\mathrm{C} / \mathrm{CNTs} / \mathrm{Cu}$ at $1^{\text {st }}, 2^{\text {nd }}, 10^{\text {th }}, 50^{\text {th }}$ and $100^{\text {th }}$ cycle are shown in Fig. 7 (a). At the $1^{\text {st }}$ cycle, the charge and discharge capacity are 7375 and 
$1696 \mathrm{~mA} \mathrm{~h}(\mathrm{~g} \text { of Si })^{-1}$, respectively, and this irreversible capacity is attributed to conversion reaction of $\mathrm{SiO}_{\mathrm{x}}$ to $\mathrm{Li}_{\mathrm{x}} \mathrm{Si}_{\mathrm{y}}$ and $\mathrm{Li}_{2} \mathrm{O}$, and consumption of $\mathrm{Li}$ ion to form $\mathrm{SEI}$ on surface of $\mathrm{Si}$ O-C composite, which is corresponding to in Fig. 6 (b). In addition, it reveals that the charge process was carried out at a potential below $0.4 \mathrm{~V}$ vs. $\mathrm{Li} / \mathrm{Li}^{+}$after $2^{\text {nd }}$ cycle, and discharge process began at a potential below $0.6 \mathrm{~V}$ vs. $\mathrm{Li} / \mathrm{Li}^{+}$which corresponding to reaction of amorphous $\mathrm{Si}$ to amorphous $\mathrm{Li} \mathrm{Si}$ phase and delithiation of amorphous $\mathrm{Li}_{\mathrm{x}} \mathrm{Si}$ to amorphous $\mathrm{Si}$. These behaviors are corresponding to cathodic peak around $0.2 \mathrm{~V}$ vs. $\mathrm{Li} / \mathrm{Li}^{+}$and anodic peak below $0.6 \mathrm{~V}$ vs. $\mathrm{Li} / \mathrm{Li}^{+}$in $\mathrm{CV}$ results.

Figure 7 (b) indicates the cycle abilities of $\mathrm{Si}-\mathrm{O}-\mathrm{C} / \mathrm{Cu}$ and $\mathrm{Si}-\mathrm{O}-\mathrm{C} / \mathrm{CNTs} / \mathrm{Cu}$ prepared by electrodeposition at 2 coulomb $\mathrm{cm}^{-2}$ of passing charge for 100 cycles with their coulomb efficiency. As mentioned above, irreversible capacity of $\mathrm{Si}-\mathrm{O}-\mathrm{C} / \mathrm{Cu}$ and $\mathrm{Si}-\mathrm{O}-\mathrm{C} / \mathrm{CNTs} / \mathrm{Cu}$ substrate was observed at $1^{\text {st }}$ cycle, resulting in low coulomb efficiency (discharge capacity/charge capacity) of 24.1 and $25.3 \%$ at $1^{\text {st }}$ cycle, respectively. However, the coulomb efficiency of $\mathrm{Si}-\mathrm{O}-\mathrm{C} / \mathrm{Cu}$ and $\mathrm{Si}-\mathrm{O}-\mathrm{C} / \mathrm{CNTs} / \mathrm{Cu}$ was increase up to 86.7 and $87.1 \%$ after $2^{\text {nd }}$ cycle. It means that the Si-O-C composites deposited on both substrates suffer from coulomb efficiency fading because of lithiation and formation of SEI at $1^{\text {st }}$ cycle.

The discharge capacity of Si-O-C/Cu is 1173,934 and $840 \mathrm{~mA} \mathrm{~h}(\mathrm{~g} \text { of Si})^{-1}$ at $1^{\text {st }}, 50^{\text {th }}$ and $100^{\text {th }}$ cycle, respectively. However Si-O-C composites deposited onto CNTs/Cu substrate show higher discharge capacity of 1696, 1268 and $1078 \mathrm{~mA} \mathrm{~h}(\mathrm{~g} \text { of Si})^{-1}$ at same cycles. From this research, as mentioned above, we can surmise that the high electric conductivity of CNTs layer might lead to different $\mathrm{Si}$ concentration of $\mathrm{Si}-\mathrm{O}-\mathrm{C} / \mathrm{CNTs} / \mathrm{Cu}$ and $\mathrm{Si}-\mathrm{O}-\mathrm{C} / \mathrm{Cu}$ during electrodeposition. For this reason, $\mathrm{Si}-\mathrm{O}-\mathrm{C} / \mathrm{CNTs} / \mathrm{Cu}$ can have increased deposited $\mathrm{Si}$ amounts than $\mathrm{Si}-\mathrm{O}-\mathrm{C} / \mathrm{Cu}$ with higher discharge capacity for 100 cycles.

The discharge areal capacity of $\mathrm{Si}-\mathrm{O}-\mathrm{C} / \mathrm{Cu}$ and $\mathrm{Si}-\mathrm{O}-\mathrm{C} / \mathrm{CNTs} / \mathrm{Cu}$ was compared and presented 
in Fig. 7 (c). This results demonstrate that the Si-O-C composites deposited on $\mathrm{CNTs} / \mathrm{Cu}$ substrate delivered a higher discharge areal capacity of 0.10 and $0.06 \mathrm{~mA} \mathrm{~h} \mathrm{~cm}^{-2}$ at $1^{\text {st }}$ and $100^{\text {th }}$ cycle, respectively, than $\mathrm{Si}-\mathrm{O}-\mathrm{C} / \mathrm{Cu}$ which has discharge areal capacity of 0.08 and $0.05 \mathrm{~mA} \mathrm{~h}$ $\mathrm{cm}^{-2}$ at $1^{\text {st }}$ and $100^{\text {th }}$ cycle, respectively. The discharge areal capacity of both Si-O-C composites deposited on as-received $\mathrm{Cu}$ and $\mathrm{CNTs} / \mathrm{Cu}$ substrate depending on quantity of electricity for electrodeposition were compared in Fig. 7 (d). As mentioned in Fig. 7 (c), the Si-O-C composites deposited on $\mathrm{CNTs} / \mathrm{Cu}$ substrate delivered a higher areal capacity than $\mathrm{Si}-\mathrm{O}-\mathrm{C} / \mathrm{Cu}$ but that is not much different, only $0.02 \mathrm{~mA} \mathrm{~h} \mathrm{~cm}^{-2}$ at $1^{\text {st }}$ cycle. However, as increase the quantity of electricity for electrodeposition, the differences of areal capacity from both samples are gradually increasing until 15 coulomb $\mathrm{cm}^{-2}$ of passing charge. At 8 coulomb cm $\mathrm{cm}^{-2}$ of passing charge, the Si-O-C/Cu has highest discharge areal capacity of $0.13 \mathrm{~mA} \mathrm{~h} \mathrm{~cm}^{-2}$ at 1 st cycle and it began to decline until $0.03 \mathrm{~mA} \mathrm{~h} \mathrm{~cm} \mathrm{~cm}^{-2}$ at 15 coulomb $\mathrm{cm}^{-2}$ of passing charge at $1^{\text {st }}$ cycle. On the other hand, Si-O-C composites deposited on $\mathrm{CNTs} / \mathrm{Cu}$ substrate show increased discharge areal capacity even at 15 coulomb cm${ }^{-2}$ of $0.49 \mathrm{~mA} \mathrm{~h} \mathrm{~cm}^{-2}$ at $1^{\text {st }}$ cycle due to its enhanced adhesion strength between Si-O-C composites and $\mathrm{Cu}$ substrate which is corresponding to Fig. 2. From areal capacity results, we could identify that the Si-O-C composites deposited on $\mathrm{CNTs} / \mathrm{Cu}$ substrate show higher areal capacity because $\mathrm{Si}-\mathrm{O}-\mathrm{C} / \mathrm{CNTs} / \mathrm{Cu}$ has increased deposited $\mathrm{Si}$ amounts than $\mathrm{Si}-\mathrm{O}-\mathrm{C} / \mathrm{Cu}$ owing to enhanced adhesion strength by introducing of CNTs layer via high voltage electrophoretic deposition. In addition, we could confirm that Si$\mathrm{O}-\mathrm{C} / \mathrm{CNTs} / \mathrm{Cu}$ prepared 15 coulomb $\mathrm{cm}^{-2}$ of passing charge shows higher areal capacity than our previous report (Si-O-C/CNTs/Cu: $0.49 \mathrm{~mA} \mathrm{~h} \mathrm{~cm}{ }^{-2}$, Si-O-C/NMS composites: $0.18 \mathrm{~mA} \mathrm{~h}$ $\mathrm{cm}^{-2}$ at $1^{\text {st }}$ cycle) [29].

To identify the influence of introduced CNTs layer during charge/discharge process, C-rate performance was measured depending on various $\mathrm{C}$-rate values from $0.1,0.2,0.5$, and $1.0 \mathrm{C}$ and $0.1 \mathrm{C}$ again for 25 cycles in Fig. 7 (e). In general, Si-O-C/CNTs/Cu has higher discharge 
capacity than $\mathrm{Si}-\mathrm{O}-\mathrm{C} / \mathrm{Cu}$, and these two samples show almost same reduction rate of discharge capacity depending on various loading current. For more detail analysis, the C-rate results was converted to discharge capacity retention ratio, which is shown in Fig. 7 (f). From $1^{\text {st }}$ to $5^{\text {th }}$ cycle, the discharge capacity retention ratio of $\mathrm{Si}-\mathrm{O}-\mathrm{C} / \mathrm{Cu}$ and $\mathrm{Si}-\mathrm{O}-\mathrm{C} / \mathrm{CNTs} / \mathrm{Cu}$ show similar values around of 97.9 and $95.5 \%$, respectively. However, discharge capacity decreasing rate of $\mathrm{Si}-\mathrm{O}-\mathrm{C} / \mathrm{Cu}$ have been decreased rapidly around $20.6,18.4$, and $19.7 \%$ per 5 cycles for 20 cycles. By contrast, discharge capacity decreasing rate of $\mathrm{Si}-\mathrm{O}-\mathrm{C} / \mathrm{CNTs} / \mathrm{Cu}$ shows slight decreasing rate of $9.3,9.6$, and $8.5 \%$ per 5 cycles for 20 cycles. Furthermore, the discharge capacity retention ratio of $\mathrm{Si}-\mathrm{O}-\mathrm{C} / \mathrm{Cu}$ was decreased around $18.9 \%$ from $21^{\text {st }}-25^{\text {th }}$ cycle compared to initial value. On the other hand, $\mathrm{Si}-\mathrm{O}-\mathrm{C} / \mathrm{CNTs} / \mathrm{Cu}$ shows decreasing rate around of only $7.3 \%$ from $21^{\text {st }}-25^{\text {th }}$ cycle in comparison with $1^{\text {st }}$ cycle. For an easier understanding, discharge capacity retention rate of both samples are presented in Fig. S5 with one cycle per each C-rate. From C-rate performance results, we suppose that the high conductivity of the CNTs reduces the internal strain from volume change of Si during charge/discharge cycling, resulting in good C-rate performance at high $\mathrm{C}$-rate values. In addition, we suggest that the CNTs layer employed as electric pathway, lead to enhanced electrochemical properties such as higher discharge capacity and good recovery rate at high $\mathrm{C}$-rate values. Besides, the electric path way could play a role to decrease the internal resistance in Si-O-C composites during charge/discharge process. As seen the charge/discharge profile at $100^{\text {th }}$ cycle (in Fig. S6), it is believed that $\mathrm{Si}-\mathrm{O}-\mathrm{C} / \mathrm{CNTs} / \mathrm{Cu}$ exhibits the lower internal resistance voltage drop (IR drop) than $\mathrm{Si}-\mathrm{O}-\mathrm{C} / \mathrm{Cu}$, results in higher discharge capacity with good retention ratio of Si-O$\mathrm{C} / \mathrm{CNTs} / \mathrm{Cu}$. 

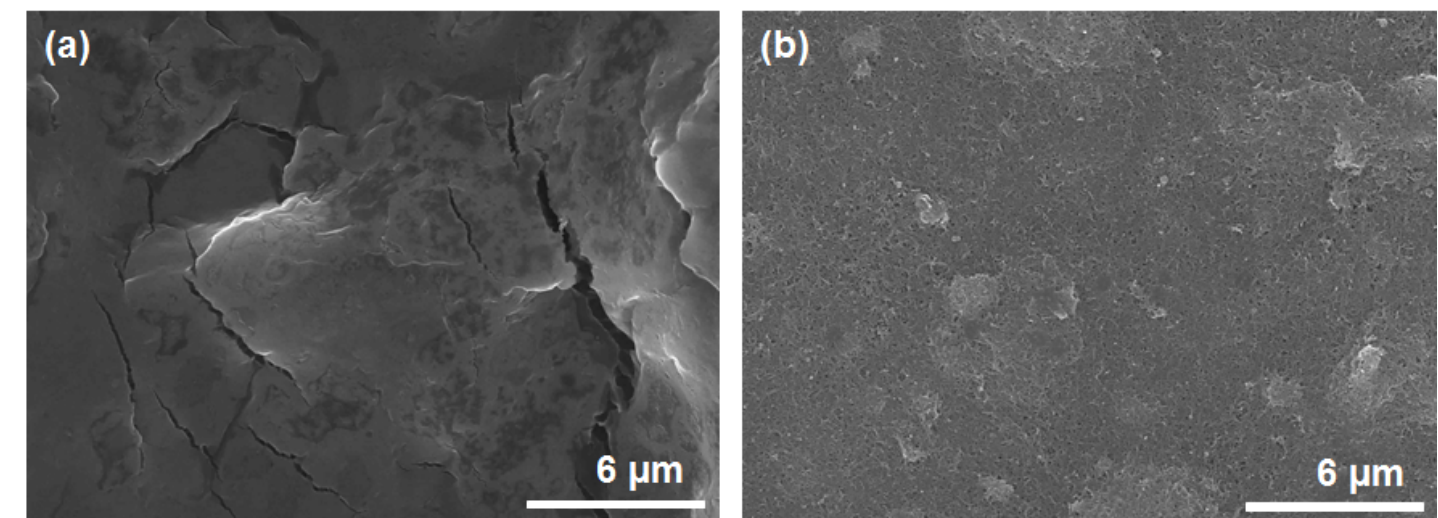

Figure 8. Plane view FE-SEM images of (a) $\mathrm{Si}-\mathrm{O}-\mathrm{C} / \mathrm{Cu}$ and (b) $\mathrm{Si}-\mathrm{O}-\mathrm{C} / \mathrm{CNTs} / \mathrm{Cu}$ synthesized by electrodeposition with 2 coulomb cm$~_{-2}$ of passing charge after charge/ discharge process for 100 cycles at $0.1 \mathrm{C}$ rate.

The morphological characteristics of Si-O-C/Cu and Si-O-C/CNTs/Cu after 100 cycles were measured by FE-SEM analysis and presented in Fig. 8. The Si-O-C/Cu shows the cracked surface due to volume change during charge/discharge cycling, lead to occur isolated $\mathrm{Si}$ particles from current collector and it is a critical reason of discharge capacity fading. However, Fig. 8 (b) depicts non-cracked surface of Si-O-C/CNTs/Cu even after charge/discharge cycling for 100 cycles. In addition, we could confirm that Si-O-C composites were deposited onto CNTs and entangled together. To summarize, Si-O-C particles were intertwined with CNTs anchor layer to prevent cracks on their surface, lead to enhanced adhesion strength between SiO-C composites with $\mathrm{Cu}$ substrate. Moreover, the CNTs anchor layer electrophoretic deposited $\mathrm{Cu}$ substrate can withstand the much amounts of Si-O-C composite at large passing charge of electrodeposition even at 15 coulomb $\mathrm{cm}^{-2}$, resulting in enhanced deposited $\mathrm{Si}$ amounts compared to as-received $\mathrm{Cu}$ substrate without CNTs anchor layer. In other words, CNTs layer could play a role to bind Si-O-C composites and space of CNTs layer can be endurable the volume change during charge/discharge cycling, resulting in enhanced deposited Si amounts and higher discharge capacity for 100 cycles. 


\section{Conclusion}

We have prepared the $\mathrm{CNTs} / \mathrm{Cu}$ substrate by high voltage electrophoretic deposition in IPA for improving adhesion strength between $\mathrm{Si}-\mathrm{O}-\mathrm{C}$ composites and $\mathrm{Cu}$ substrate, and $\mathrm{Si}-\mathrm{O}-\mathrm{C}$ composites deposited onto obtained $\mathrm{CNTs} / \mathrm{Cu}$ substrate by electrodeposition from reduction of $\mathrm{SiCl}_{4}$. The $\mathrm{Si}-\mathrm{O}-\mathrm{C} / \mathrm{CNTs} / \mathrm{Cu}$ shows the higher discharge capacity than $\mathrm{Si}-\mathrm{O}-\mathrm{C} / \mathrm{Cu}$ of ca. 1078 and $840 \mathrm{~mA} \mathrm{~h}(\mathrm{~g} \text { of Si})^{-1}$ at $100^{\text {th }}$ cycle, respectively. Furthermore, Si-O-C/CNTs/Cu shows the good cycle ability for 100 cycles, and increased discharge areal capacity of $0.49 \mathrm{~mA} \mathrm{~h} \mathrm{~cm} \mathrm{~cm}^{-2}$ at 15 coulomb $\mathrm{cm}^{-2}$ of passing charge at $1^{\text {st }}$ cycle, it is higher than our previous report ( $\mathrm{Si}-\mathrm{O}-$ C/NMS composites: $0.18 \mathrm{~mA} \mathrm{~h} \mathrm{~cm}^{-2}$ at 15 coulomb $\mathrm{cm}^{-2}$ of passing charge at $1^{\text {st }}$ cycle). In addition, CNTs anchor layer on $\mathrm{Cu}$ substrate achieves higher discharge capacity retention at various $\mathrm{C}$-rate values than as-received $\mathrm{Cu}$ substrate because of enhanced adhesion strength and high electric conductivity of CNTs. The discharge capacity retention of $\mathrm{Si}-\mathrm{O}-\mathrm{C} / \mathrm{Cu}$ is $49.94 \%$ at $1.0 \mathrm{C}$-rate, whereas the $\mathrm{Si}-\mathrm{O}-\mathrm{C} / \mathrm{CNTs} / \mathrm{Cu}$ shows improved discharge capacity retention of $69.81 \%$ at $1.0 \mathrm{C}$-rate. The reasons of these superb results are enhanced adhesion strength between $\mathrm{Si}-\mathrm{O}-\mathrm{C}$ and $\mathrm{CNTs} / \mathrm{Cu}$ substrate and good electric conductivity of $\mathrm{CNTs}$, and it can complement the deterioration of cell performance. From these results, it is clear that CNTs layer can perform as not only additive for increasing adhesion strength but also electron transfer pathway for high performance Si-O-C composites as anode for LIBs.

\section{Acknowledgements}

This work was partly supported by "Advanced Low Carbon Technology Research and Development Program, Specially Promoted Research for Innovative Next Generation Batteries (ALCA-SPRING)” from Japan Science and Technology Agency (JST), Japan. 


\section{References}

[1] J. Y. Lim, C. S. Lee, J. M. Lee, J. Ahn, H. H. Cho, J. H. Kim, J. Power. Sources, 301 (2016) 18-28.

[2] E. Tsujji, T. Yamasaki, Y. Aoki, S. G. Park, K. I. Shimizu, H. Habazaki, Carbon, 87 (2015) 1- 9 .

[3] J. J. Yang, C. H. Choi, H. B. Seo, H. J. Kim, S. G. Park, Electrochim. Acta, 86 (2012) 277- 281.

[4] J. J. Yang, J. H. Choi, H. J. Kim, M. Morita, S. G. Park, J. Ind. Eng. Chem., 19 (2013) 1648-1652.

[5] M. Jeong, Y. Yokoshima, H. Nara, Y. Momma, T. Osaka, J. Power. Sources, 275 (2015) 525-530.

[6] M. Jeong, Y. Yokoshima, H. Nara, Y. Momma, T. Osaka, J. Electrochem. Soc., 161 (2014) D3025-D3031.

[7] M. Jeong, Y. Yokoshima, H. Nara, Y. Momma, T. Osaka, RSC Adv., 4 (2014) 2687226880 .

[8] B. Wang, W. A. Abdulla, D. Wang, X. S. Zhao, Energy Environ. Sci., 8 (2015) 869-875.

[9] C. Wang, L. Wu, H. Wang, W. Zuo, Y. Li, J. Liu, Adv. Funct. Mater., 25 (2015) 35243533 .

[10] S. M. Seidel, S. Jeschke, P. Vettikuzha, H.-D. Wiemhöfer, Chem. Commun., 51 (2015) 12048-12051.

[11] S.R. Sivakkumar, and A.G. Pandolfo, Electrochim. Acta, 65 (2012) 280-287.

[12] Y. Wang, L. Tian, A. Yao, F. Li, S. Li, S. Ye, Electrochim. Acta, 163 (2015) 71-76.

[13] H. F. Xiang, Z. D. Li, K. Xie, J. Z. Jiang, J. J. Chen, P. C. Lian, J. S. Wu, Y. Yu, H. H. Wang, RSC Adv., 2 (2012) 6792-6799.

[14] S. K. Ahn, J. J. Yang, H. I. Kim, H. Habazaki, S. G. Park, Chem. Lett., 43 (2014) 898900.

[15] B. J. Landi, M. J. Ganter, C. D. Cress, R. A. DiLeo, R. P. Raffaelle, Energy Environ. Sci., 2 (2009) 638-654.

[16] M. Yoshio, H. Wang, K. Fukuda, T. Umeno, T. Abeb, Z. Ogumi, J. Mater. Chem., 14 (2004) 1754-1758.

[17] Z. Luo, Q. Xiao, G. Lei, Z. Li, C. Tang, Carbon, 98 (2016) 373-380.

[18] M. S. Wang, W. L. Song, J. Wang, L. Z. Fan, Carbon, 82 (2015) 337-345. 
[19] H. Li, Z. Wang, L. Chen, X. Huang, Adv. Mater., 21 (2009) 4593-4607.

[20] Z. Favors, W. Wang, H. H. Bay, Z. Mutlu, K. Ahmed, C. Liu, M. Ozkan, C. S. Ozkan, Sci. Rep., 4 (2014) No. 5623-5629.

[21] J. K. Lee, K. B. Smith, C. M. Hayner, H. H. Kung, Chem. Commun., 46 (2010) $2025-$ 2027.

[22] H. Tang, J. P. Tu, X. Y. Liu, Y. J. Zhang, S. Huang, W. Z. Li, X. L. Wang, C. D. Gu, J. Mater. Chem. A, 2 (2014) 5834-5840.

[23] Q. Si, M. Matsui, T. Horiba, O. Yamamoto, Y. Takeda, N. Seki, N. Imanishi, J. Power. Sources, 241 (2013) 744-750.

[24] Q. Sa, Y. Wang, J. Power. Sources, 208 (2012) 46-51.

[25] Y. Zhao, X. Liu, H. Li, T. Zhai, H. Zhou, Chem. Commun., 48 (2012) 5079-5081.

[26] B. Liu, X. Wang, H. Chen, Z. Wang, D. Chen, Y. B. Cheng, C. Zhou, G. Shen, Sci. Rep., 3 (2013) No. 1622-1628.

[27] S. Komaba, N. Yabuuchi,T. Ozeki, Z. Han, K. Shimomura, H. Yui, Y. Katayama, T. Miura, J. Phys. Chem. C, 116 (2012) 1380-1389.

[28] H. Nara, T. Yokoshima, T. Momma, Tetsuya Osaka, Energy Environ. Sci., 5 (2012) 65006505 .

[29] T. Hang, H. Nara, T. Yokoshima, T. Momma, T. Osaka, J. Power. Sources, 222 (2013) 503-509.

[30] S. Hossain, Y. K. Kim, Y. Saleh, R. Loutfy, J. Power. Sources, 114 (2003) 264-276.

[31] E. Frackowiak, F. Béguin, Carbon, 40 (2002) 1775-1787.

[32] Z. Zhang, J. Peng, H. Zhang, Appl. Phys. Lett., 79 (2001) 3515-3517.

[33] W. X. Chen, J. Y. Lee, Z. Liu, Carbon, 41 (2003) 959-966.

[34] J. Huang, Z. Jiang, Electrochim. Acta, 53 (2008) 7756-7759.

[35] B. -J. Kim, J. -S. Park, Y. -J. Hwang, J. -S. Park, Appl. Surf. Sci., 380 (2016) 2-7.

[36] H. Zhao, H. Song, Z. Li, G. Yuan, Y. Jin, Appl. Surf. Sci., 251 (2005) 242-244.

[37] B. Gao, G. Z. Yue, Q. Qiu, Y. Cheng, H. Shimoda, L. Fleming, O. Zhou, Adv. Mater., 13 (2001) 1770-1773.

[38] L. Wang, Y. Chen, T. Chen, W. Que, Z. Sun, Mater. Lett., 61 (2007) 1265-1269.

[39] M. S. Wu, C. Y. Huang, K. H. Lin, Electrochem. Solid St., 12 (2009) A129-A131.

[40] S. Santhanagopalan, F.Teng, D. D. Meng, Langmuir, 27 (2010) 561-569. 
(a)

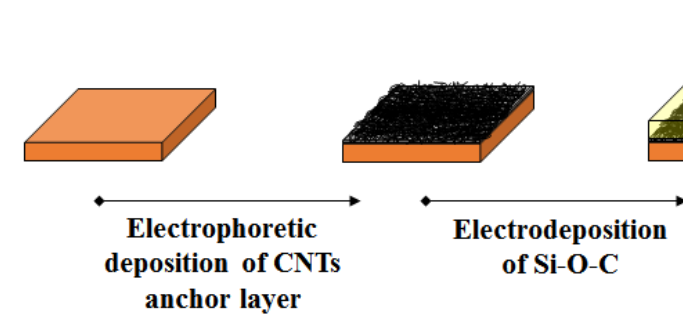

(c) (d) $\bigcirc$ Si-O-C composite

Electrophoretic deposited CNTs

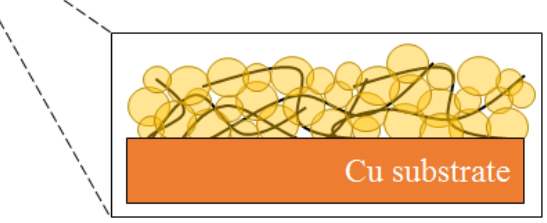

Figure 1. Schematic figures explaining Si-O-C composites deposition process on $\mathrm{CNTs} / \mathrm{Cu}$ Substrate; (a) as-received Cu substrate, (b) electrophoretically deposited CNTs anchor layer on $\mathrm{Cu}$ substrate, (c) electrodeposited $\mathrm{Si}-\mathrm{O}-\mathrm{C}$ on $\mathrm{CNTs} / \mathrm{Cu}$ substrate, and (d) $\mathrm{Si}-\mathrm{O}-\mathrm{C} / \mathrm{CNTs} / \mathrm{Cu}$ anode with cross-section view. 

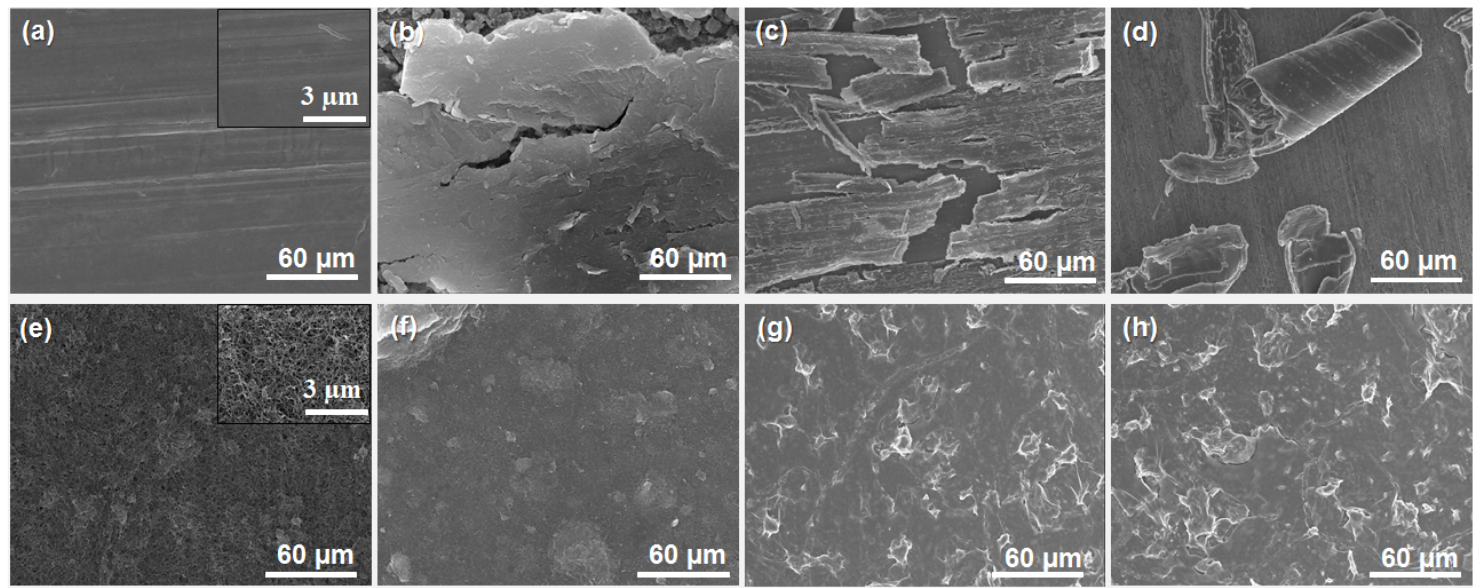

Figure 2. Plane view FE-SEM images of (a) as-received $\mathrm{Cu}$ substrate, and $\mathrm{Si}-\mathrm{O}-\mathrm{C}$ composites deposited on as-received $\mathrm{Cu}$ substrate at (b) 2, (c) 8, and (d) 15 coulomb cm $\mathrm{cm}^{-2}$ passing charge. The plane view of (e) CNTs/Cu substrate, Si-O-C composites deposited on CNTs/Cu substrate at (f) $2,(\mathrm{~g}) 8$, and (h) 15 coulomb cm $\mathrm{cm}^{-2}$ of passing charge. 

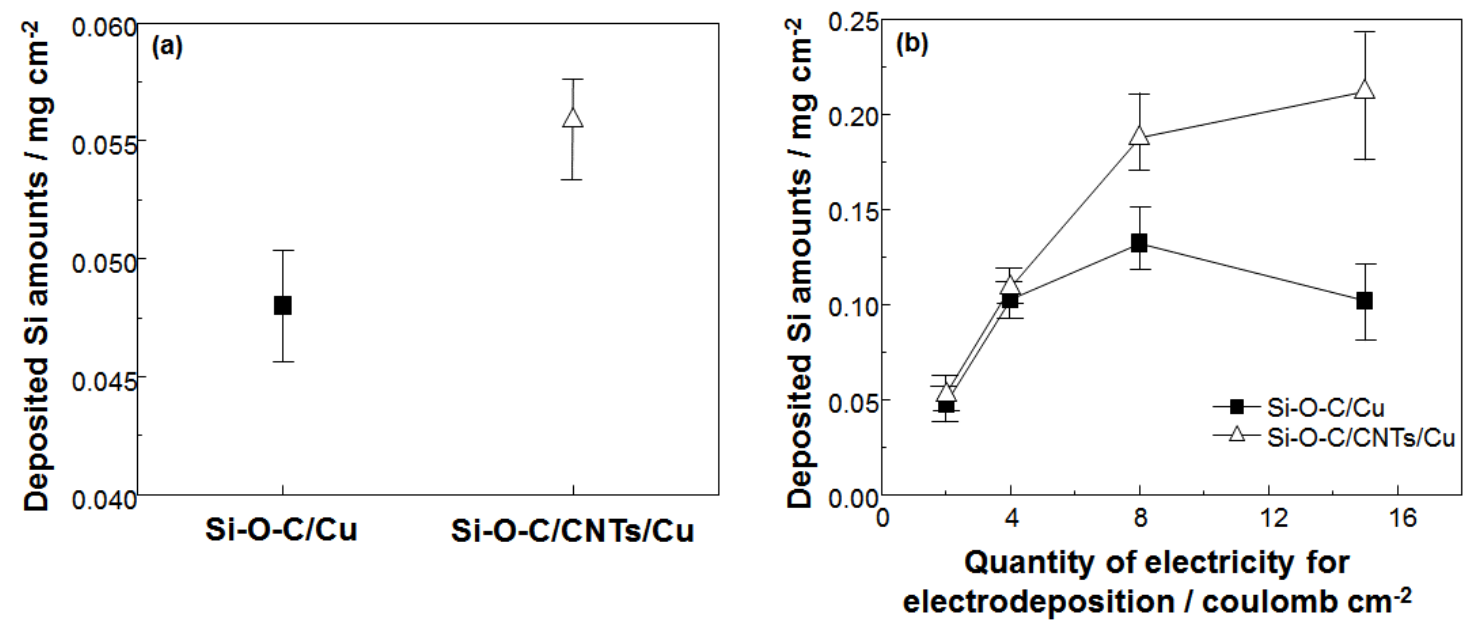

Figure 3. (a) Comparison of deposited Si amounts of Si-O-C composites deposited on to asreceived $\mathrm{Cu}$ substrate and $\mathrm{CNTs} / \mathrm{Cu}$ substrate at 2 coulomb $\mathrm{cm}^{-2}$ of passing charge, and (b) depending on various quantity of electricity for electrodeposition from 2 to 15 coulomb $\mathrm{cm}^{-2}$ of passing charge. 

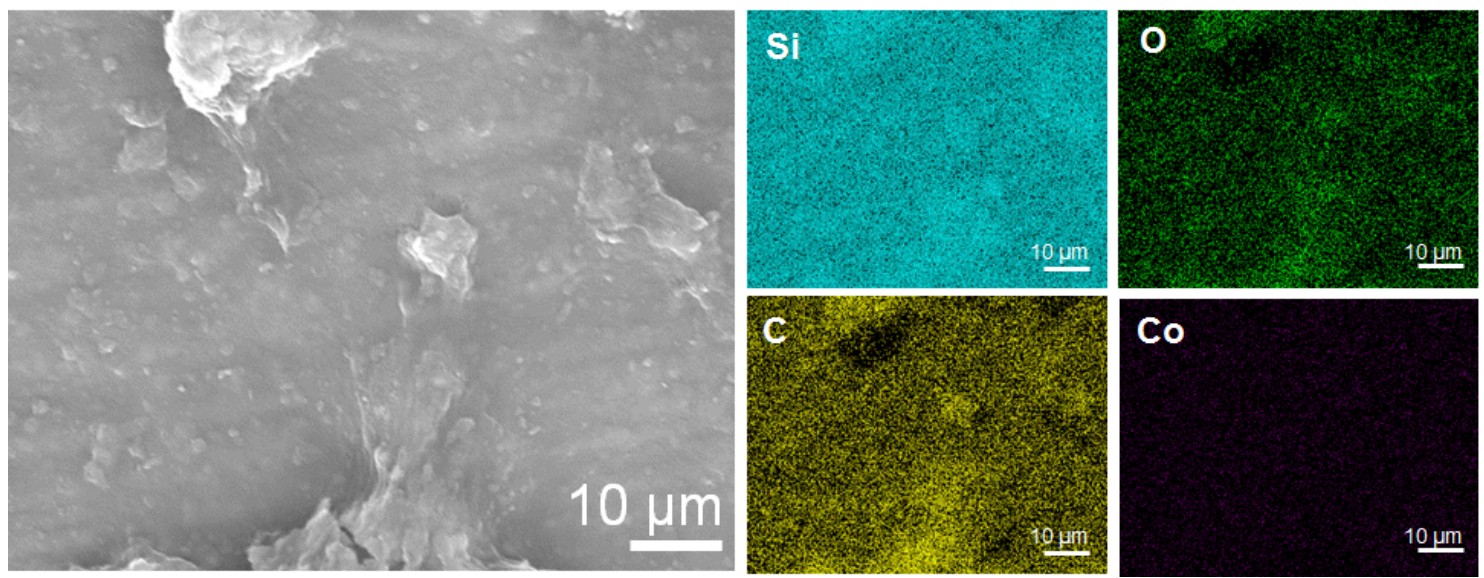

Figure 4. Plane view SEM image of $\mathrm{Si}-\mathrm{O}-\mathrm{C} / \mathrm{CNTs} / \mathrm{Cu}$ prepared by electrodeposition at 2 coulomb $\mathrm{cm}^{-2}$ of passing charge with elemental mapping of silicon, oxygen, carbon and cobalt. 

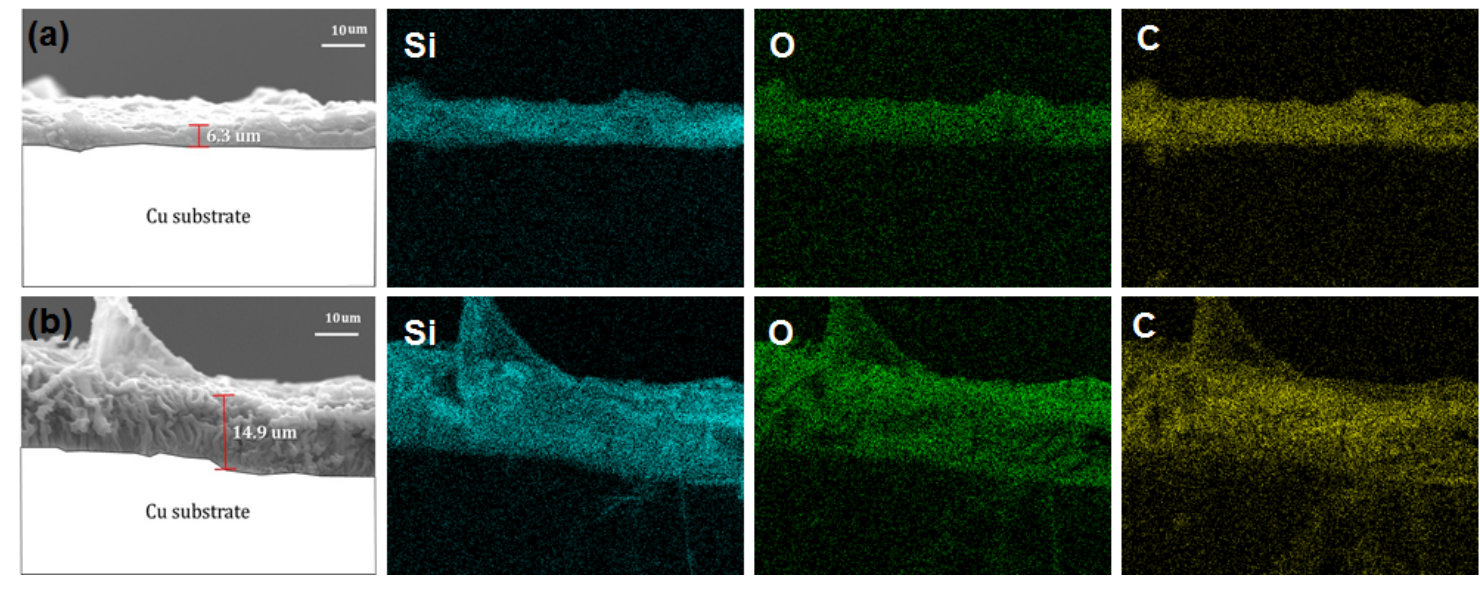

Figure 5. SEM images of cross-section of $\mathrm{Si}-\mathrm{O}-\mathrm{C} / \mathrm{CNTs} / \mathrm{Cu}$ prepared by electrodeposition at 2 coulomb $\mathrm{cm}^{-2}$ of passing charge (a) before and (b) after charge/discharge with elemental mapping of silicon, oxygen, and carbon. 

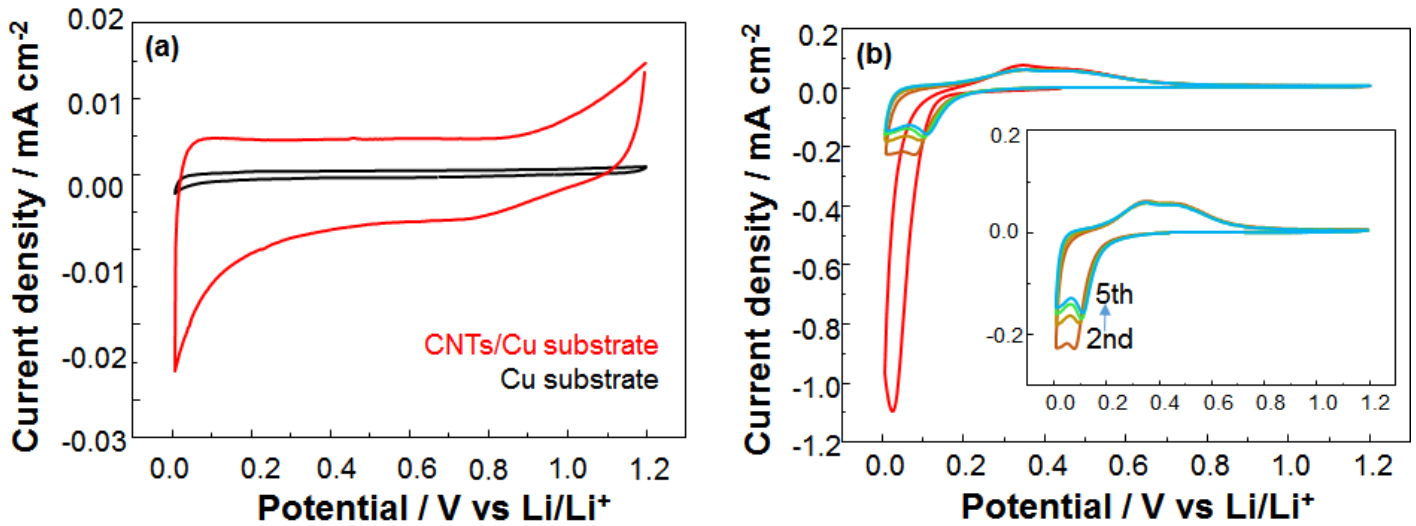

Figure 6. $\mathrm{CV}$ results of (a) as-receive $\mathrm{Cu}$ and $\mathrm{CNTs} / \mathrm{Cu}$ substrate and (b) Si-O-C/CNTs/Cu for 5 cycles synthesized by electrodeposition with 2 coulomb $\mathrm{cm}^{-2}$ of passing charge. The potential range is between 1.2 and $0.01 \mathrm{Vvs} . \mathrm{Li} / \mathrm{Li}^{+}$at a scan rate of $0.1 \mathrm{mV} \mathrm{s}^{-1}$. The inset in (b) indicates the $\mathrm{CV}$ results of $\mathrm{Si}-\mathrm{O}-\mathrm{C} / \mathrm{CNTs} / \mathrm{Cu}$ from $2^{\text {nd }}$ to $5^{\text {th }}$ cycle. 

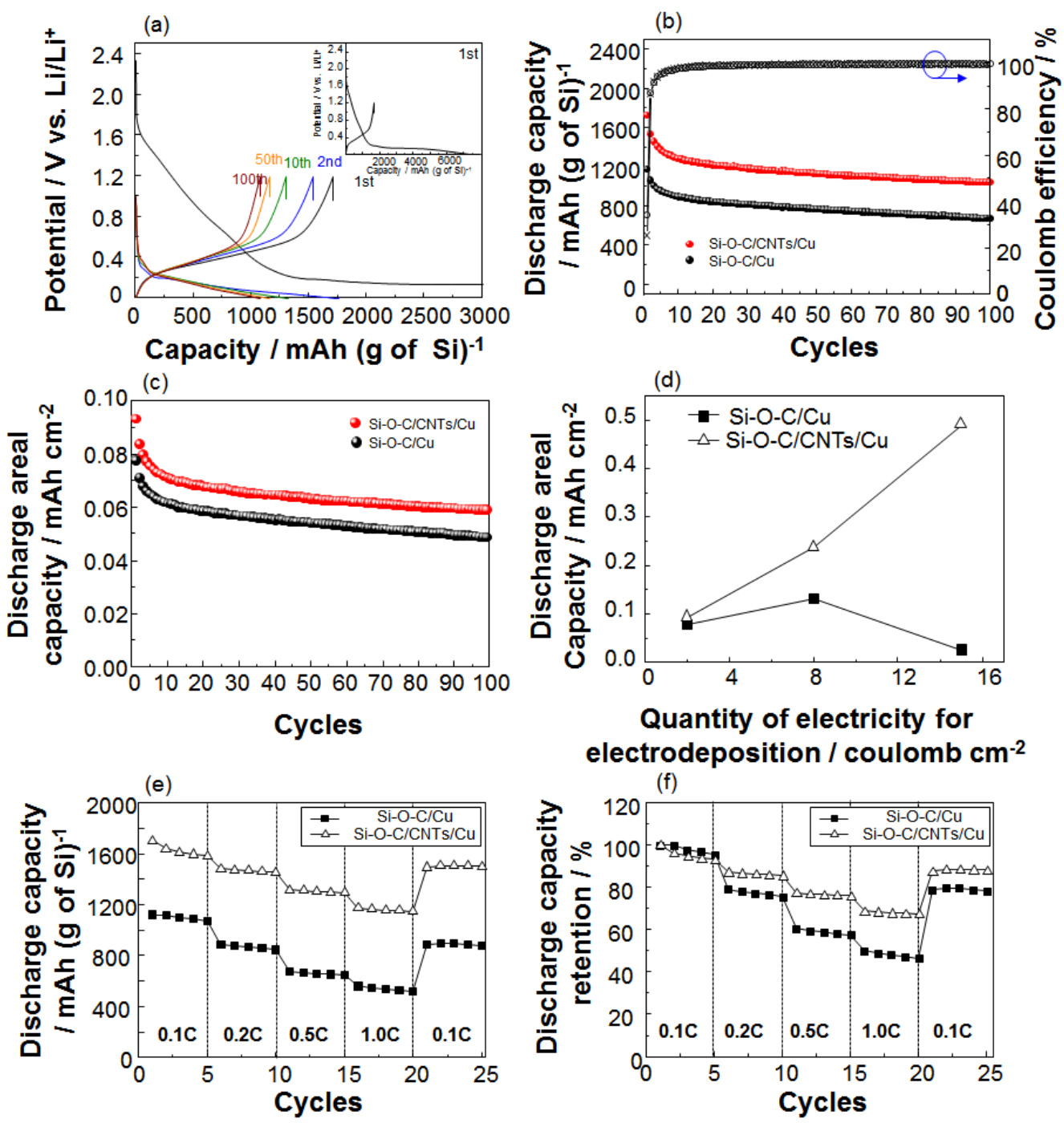

Figure 7. (a) Charge/discharge profiles of $\mathrm{Si}-\mathrm{O}-\mathrm{C} / \mathrm{CNTs} / \mathrm{Cu}$ from $1^{\text {st }}$ to $100^{\text {th }}$ cycle, the potential range is $0.01-1.2 \mathrm{~V}$ vs. $\mathrm{Li} / \mathrm{Li}^{+}$at $0.1 \mathrm{C}$-rate, (b) comparison of cycle abilities with Si$\mathrm{O}-\mathrm{C} / \mathrm{Cu}$ and $\mathrm{Si}-\mathrm{O}-\mathrm{C} / \mathrm{CNTs} / \mathrm{Cu}$ for 100 cycles, (c) discharge areal capacity of both samples, (d) areal capacity depending on quantity of electricity from 2 to 15 coulomb $\mathrm{cm}^{-2}$ of passing charge at $1^{\text {st }}$ cycle, (e) C-rate performance, and (f) discharge capacity retention rate at various C-rate from 0.1 to $1 \mathrm{C}$ and $0.1 \mathrm{C}$ again for 25 cycles. (a) - (d) were tested at $0.1 \mathrm{C}$-rate. The discharge capacity values of $\mathrm{Si}-\mathrm{O}-\mathrm{C} / \mathrm{Cu}$ and $\mathrm{Si}-\mathrm{O}-\mathrm{C} / \mathrm{CNTs} / \mathrm{Cu}$ were normalized with the calculated $\mathrm{Si}$ amounts from ICP results. The all $\mathrm{Si}-\mathrm{O}-\mathrm{C}$ composites were synthesized by electrodeposition with 2 coulomb $\mathrm{cm}^{-2}$ of passing charge except to (d). 

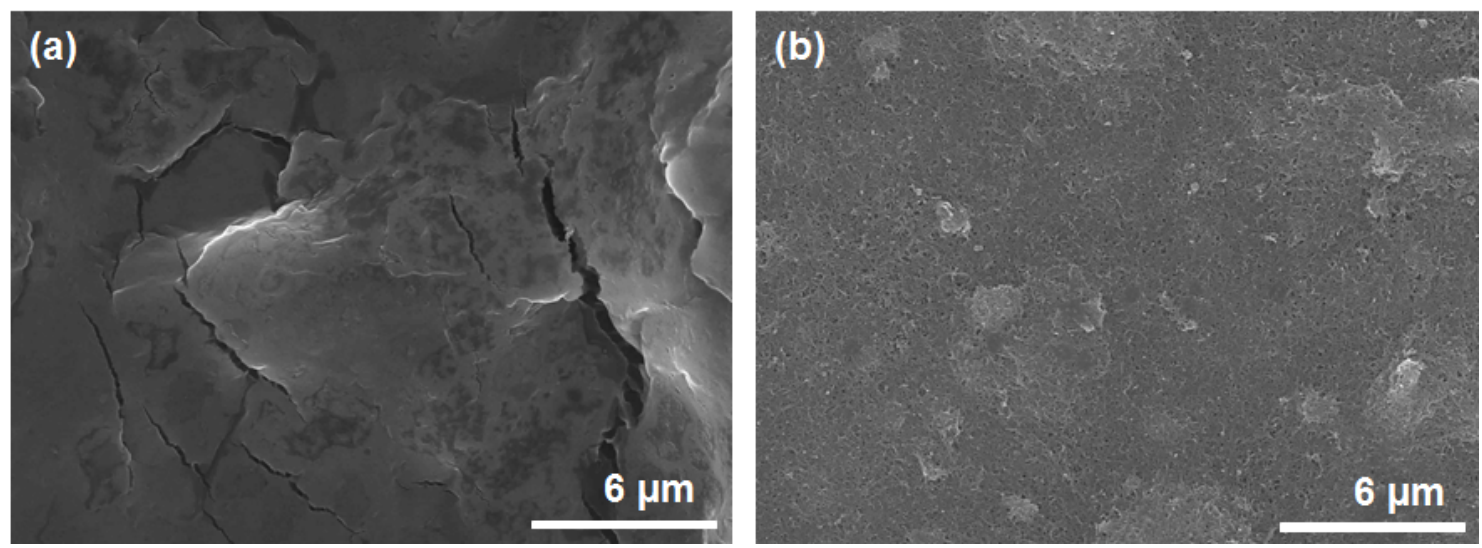

Figure 8. Plane view FE-SEM images of (a) $\mathrm{Si}-\mathrm{O}-\mathrm{C} / \mathrm{Cu}$ and (b) $\mathrm{Si}-\mathrm{O}-\mathrm{C} / \mathrm{CNTs} / \mathrm{Cu}$ synthesized by electrodeposition with 2 coulomb cm $\mathrm{cm}^{-2}$ of passing charge after charge/ discharge process for 100 cycles at $0.1 \mathrm{C}$-rate. 


\section{Graphical abstract}

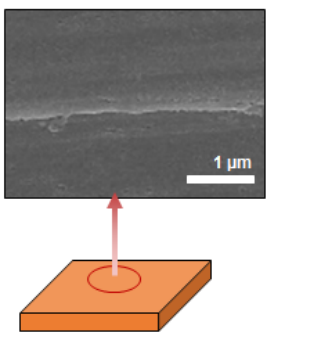

Electrophoretic deposition of CNTs anchor layer
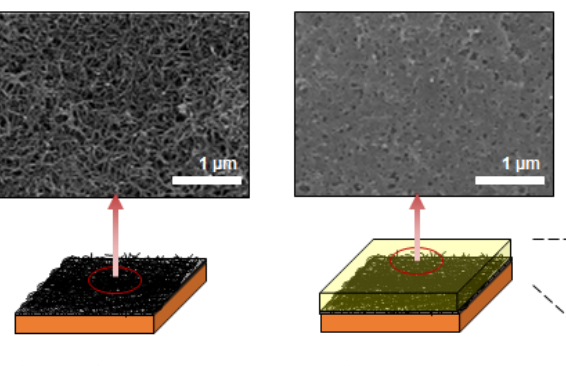

Electrodeposition of Si-O-C
Si-O-C composite

Electrophoretic deposited CNTs

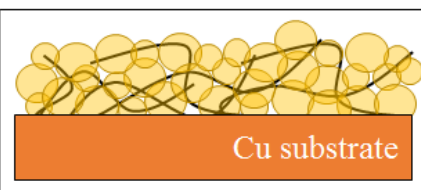

